Article

\title{
Trichormus variabilis (Cyanobacteria) Biomass: From the Nutraceutical Products to Novel EPS-Cell/Protein Carrier Systems
}

\author{
Erika Bellini ${ }^{1}$, Matteo Ciocci ${ }^{2}$, Saverio Savio ${ }^{1}$, Simonetta Antonaroli ${ }^{2}$, Dror Seliktar ${ }^{3}$, \\ Sonia Melino ${ }^{2,4, *, \dagger}$ and Roberta Congestri ${ }^{1, *, \dagger}$ \\ 1 Laboratory of Biology of Algae, Department of Biology, University of Rome Tor Vergata, 00133 Rome, Italy; \\ erikabellini1990@gmail.com (E.B.); saverio.savio@gmail.com (S.S.) \\ 2 Department of Chemical Science and Technologies, University of Rome Tor Vergata, 00133 Rome, Italy; \\ ciocci.matteo@gmail.com (M.C.); simonetta.antonaroli@uniroma2.it (S.A.) \\ 3 Department of Biomedical Engineering, Technion Israel Institute of Technology, 3200003 Haifa, Israel; \\ dror@bm.technion.ac.il \\ 4 CIMER, Center of Regenerative Medicine, University of Rome Tor Vergata, via Montpelier 1, \\ 00133 Rome, Italy \\ * Correspondence: melinos@uniroma2.it (S.M.); roberta.congestri@uniroma2.it (R.C.); \\ Tel.: +39-06-7259-4410 (S.M.); +39-06-7259-5989 (R.C.) \\ + These authors contributed equally to the work.
}

Received: 28 July 2018; Accepted: 24 August 2018; Published: 27 August 2018

\begin{abstract}
A native strain of the heterocytous cyanobacterium Trichormus variabilis VRUC 168 was mass cultivated in a low-cost photobioreactor for a combined production of Polyunsaturated Fatty Acids (PUFA) and Exopolymeric Substances (EPS) from the same cyanobacterial biomass. A sequential extraction protocol was optimized leading to high yields of Released EPS (REPS) and PUFA, useful for nutraceutical products and biomaterials. REPS were extracted and characterized by chemical staining, Reversed Phase-High-Performance Liquid Chromatography (RP-HPLC), Fourier Transform Infrared Spectroscopy (FT-IR) and other spectroscopic techniques. Due to their gelation property, REPS were used to produce a photo-polymerizable hybrid hydrogel (REPS-Hy) with addition of polyethylene glycol diacrylated (PEGDa). REPS-Hy was stable over time and resistant to dehydration and spontaneous hydrolysis. The rheological and functional properties of REPS-Hy were studied. The enzyme carrier ability of REPS-Hy was assessed using the detoxification enzyme thiosulfate:cyanide sulfur transferase (TST), suggesting the possibility to use REPS-Hy as an enzymatic hydrogel system. Finally, REPS-Hy was used as a scaffold for culturing human mesenchymal stem cells (hMSCs). The cell seeding onto the REPS-Hy and the cell embedding into 3D-REPS-Hy demonstrated a scaffolding property of REPS-Hy with non-cytotoxic effect, suggesting potential applications of cyanobacteria REPS for producing enzyme- and cell-carrier systems.
\end{abstract}

Keywords: Extracellular Polymeric Substances; hydrogel; mesenchymal stem cells; biomaterials; enzyme; omega 3; PUFA; Trichormus variabilis; Cyanobacteria

\section{Introduction}

Cyanobacteria are known as the most abundant phototrophic organisms in the Ocean. They are versatile and successfully colonize a wide range of aquatic and terrestrial habitats also thriving in strongly fluctuating environments, including the most extreme habitats on Earth [1]. Cyanobacterial diversity is enormous and represents a source of biotechnologically important organisms for new products and applications [2,3]. Commercial exploitation of cyanobacteria relies on intensive 
cultivation of biomass for the production of high-value compounds useful not only in nutraceutics, therapeutics and cosmetics but also for the production of advanced bio-material [4-10]. In this context, we focused on a strain of Trichormus variabilis (Kützing ex Bornet \& Flahault) Komárek \& Anagnostidis, isolated from sediment biofilms of a dystrophic coastal lagoon [11]. T. variabilis VRUC168 was selected based on prior studies that showed ease of growth in a range of photobioreactors (PBRs), even in suspension, self-flocculation, and interesting productivity of nutraceutical products, such as Polyunsaturated fatty acids (PUFA) and Exopolymeric Substances (EPS) [12,13].

EPS may constitute up to $60 \%$ of the dry biomass (as in the case of Nostoc commune and Trichocoleus sociatus) $[14,15]$ and can be tightly bound (cell-attached or capsular), loosely adhere (slime type) to cells or exist as free dissolved matter called Released EPS (REPS). We focused on REPS that are usually recovered from the liquid growth media of cyanobacterial cultures with a green, environmentally safe process without using chemicals $[16,17]$.

In the past few years, several studies have demonstrated a high potential application of cyanobacterial EPS that consist of various organic substances: mainly extracellular polysaccharides, uronic acids, proteins, nucleic acids and lipids [16]. Generally, they are characterized by a high complexity in terms of monosaccharidic composition. EPS can contain up to 15 sugar moieties, organized in complex repeating units and are often characterized by a high molecular weight, of up to 1-2 MDa [18]. The presence of hydrophilic moieties on one side (sulfated sugars, uronic acids and ketal-linked pyruvyl groups, among others), and hydrophobic on the other (acetyl groups, dehoxysugars and peptides) confers an amphiphilic character to the macromolecules and hence provides greater plasticity in organisms' response to surrounding environment [19]. While sulfate groups and uronic acids contribute to the anionic nature of the EPS, conferring a negative charge and a "sticky" behavior to the overall macromolecule [20-22], hydrophobic compounds are responsible for their emulsifying and rheological properties [23,24]. Due to these features, EPS are also used for the production of emulsifiers, viscosifiers, soil conditioners, biosorbants and bioflocculants [18]. Cyanobacterial EPS can play diverse roles in vivo; they form a three-dimensional network holding cells together and mediating their attachment to exposed surfaces $[12,25,26]$. A recent application of EPS-rich cyanobacteria, related to the physiological role of the EPS, is their use as nutrient supplements and physical soil amendments for the recovery of eroded soils [27-29]. EPS hydration and rheological properties are important to prevent cell desiccation and to confer pseudoplastic behavior of the extra-cellular environment $[18,19,30]$. These polymers are also involved in other relevant physiological roles from the UV protection and antibiotic resistance, to the mechanical strength and exo-enzymatic degradation activity $[18,31,32]$, which could be of interest for biomedical applications. Although these substances are widely studied, in fact, the potential applications of the EPS and REPS are not completely understood. Due to their high content of polysaccharides, these polymers are highly promising materials for applications in biomedicine and tissue engineering [33,34]. Indeed, the ability of natural polysaccharides to form hydrogels, in which three-dimensional (3D) cross-linked network structures retain a large amount of water, makes them very useful for the production of drug- or cell-carrier systems and scaffolds. In particular, therapeutic molecules or macromolecules (proteins and nucleic acids) can be entrapped into the inner structure of these hydrogels or adsorbed onto their external surface, to facilitate better targeting to organs and tissues. The embedding of active molecules into polysaccharide gels usually increases their availability, also permitting for the drug administration at lower doses and, consequently, the reduction of the toxicity for the patient [35]. Moreover, hydrogels have become important as cell-carrier systems [36,37] for the transplantation of cells in the therapy of a variety of diseases (e.g., liver failure and diabetes) [38]. In our study, a novel photo-polymerizable REPS hydrogel was produced, combining the properties of natural REPS from T. variabilis with those of the synthetic polyethylene-glycol diacrylated (PEGDa). Here, we investigated the chemico-physical and mechanical properties of this hybrid hydrogel and its potential applications in production of detoxification enzyme- and stem cell-carrier systems. Therefore, the feasibility of an integrated approach that combines the cyanobacterial biomass production with the 
extraction of unsaturated FA and the fabrication of EPS hydrogels for enzyme- and cell-carrier systems are demonstrated.

\section{Results and Discussion}

\subsection{T. variabilis Growth and Biomass Yields in the PBR}

T. variabilis VRUC168 showed the ability to grow intensively and in suspension in the low-cost, $10 \mathrm{~L}$ polyethylene vertical bags used in this study (Figure 1). These growth systems allowed optimization of the space occupied by the culture and of the illumination provided. Although biofilm growth systems have recently proved more productive $[14,39]$ to investigate potential employment of REPS as advanced bioactive material, the selected PBR configuration and material appeared satisfactory. Indeed, in our experiment, nutrient provision occurred only at the start of the PBR growth to test further reduction in biomass costs and open the path to a scale-up of T. variabilis biomass production for extraction of valued products $[7,9]$. Growth curves showed that the exponential growth reached its maximum after 20 days of culture (Figure 2A), when the maximum production of $0.787 \pm 0.010 \mathrm{gDW} \mathrm{L}^{-1}$ was also measured.

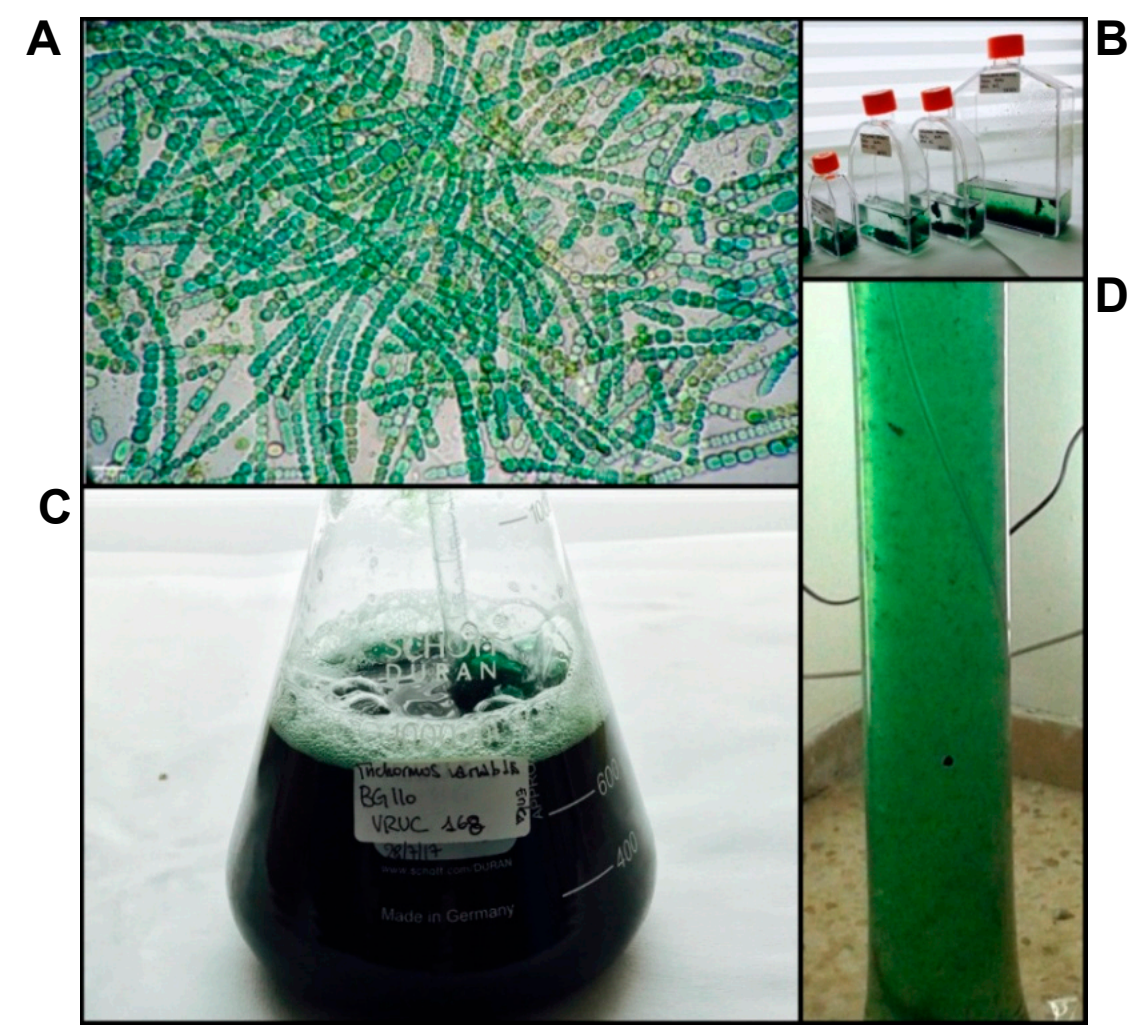

Figure 1. Biomass production. Light micrograph of T. variabilis trichomes in: culture (A); bench-scale growth system used (B,C); and pilot-scale growth system used (D).

Data obtained for the filamentous, non-heterocytous, cyanobacterium Arthrospira sp. grown in a $5 \mathrm{~L}$ reactor with air mixing show lower biomass production $\left(0.67 \pm 0.03 \mathrm{~g} \mathrm{~L}^{-1}\right)$, but higher rates, reaching exponential phase after only four days [40]. Studies conducted on mass cultivation of other filamentous forms report lower biomass and daily productivity values, as in the case of Limnothrix sp., grown in a 3.5 L PBR system $\left(0.02 \mathrm{gDW} \mathrm{L}^{-1} \mathrm{~d}^{-1} ; 0.29 \mathrm{gDW} \mathrm{L}^{-1}\right)$ [41] and Oscillatoria sp. in suspension, with $0.26 \mathrm{gDW} \mathrm{L}^{-1}$ produced after 20 days [42]. Our results show the ability of T. variabilis to grow in a simple intensive growth system and to produce rapidly a sufficient amount of biomass to be exploited for biotechnological applications. 
A

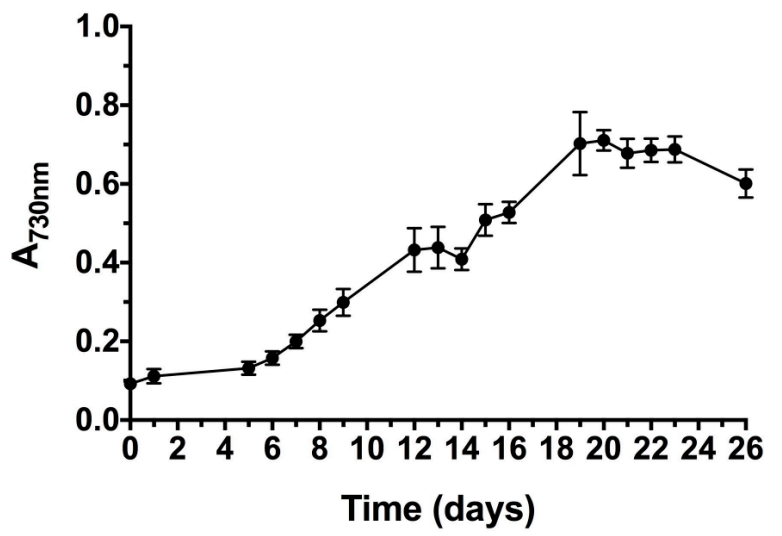

B
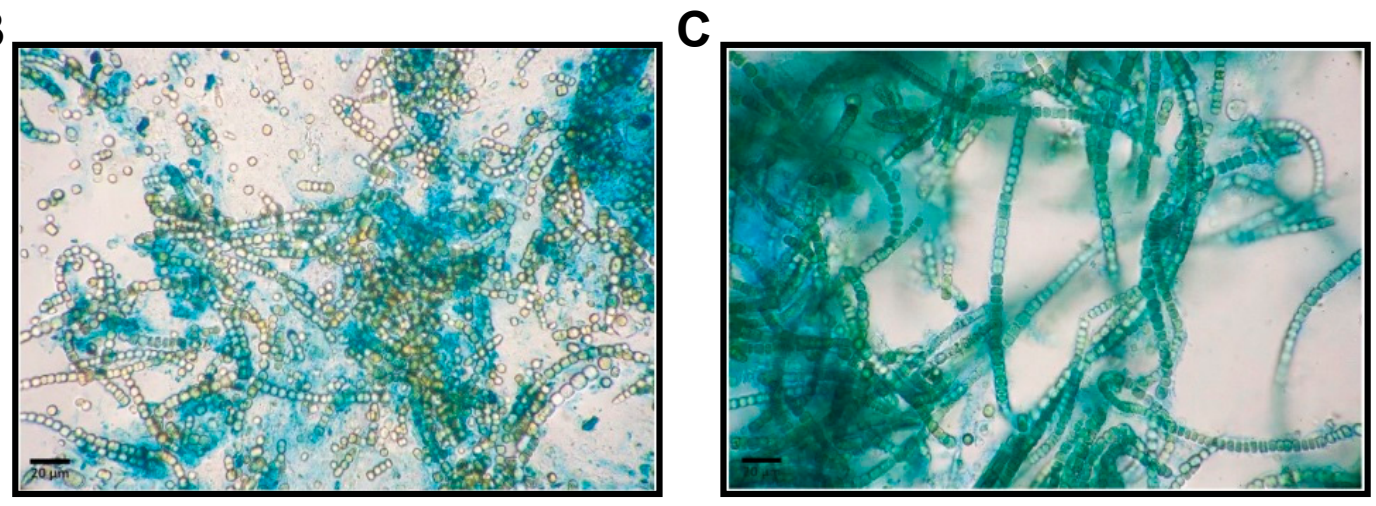

Figure 2. Growth curve recorded in polyethylene bag growth experiment (A). Light micrographs of cultures after Alcian Blue staining at pH 0.5 (B) and 2.5 (C) for sulfated and carboxylic EPS residues, respectively. Sulfated EPS were diffluent and less abundant (B), while carboxylic groups were observed in more bound matrix material $(\mathbf{C})$.

\subsection{FA Extraction and Characterization}

Among several metabolites produced from cyanobacteria, PUFA have gained much consideration due to their nutritional importance. Particularly, single FA are valued in food and pharmaceutical production due to their antioxidant, anti-inflammatory and anti-microbial activities [43,44]. With the aim of combining EPS production with that of FA from the same biomass, Fatty Acid Methyl Esters (FAME) were extracted and characterized as co-products. The total FAME content rather than its pattern is known to be dependent on the species and growth conditions, and is often considered as the most important factor for industrial applications $[45,46]$. In this study, no culture stress to induce lipid production was applied and $63.44 \pm 0.46 \mathrm{mg} / \mathrm{gDW}(6.34 \% w / w)$ of FAME were obtained from T. variabilis biomass. Our results were comparable to those obtained by Gayathri and colleagues [47] for the same species (reported as its synonym Anabaena variabilis) while were higher than those reported by the same authors for other heterocytous cyanobacteria, Nostoc commune (about $1.49 \% w / w$ ) and Nostoc muscorum (about $5 \% w / w$ ), grown without stress. The FAME composition of T. variabilis is shown in Table 1, with higher amounts of PUFA $(57.45 \pm 4.77 \%)$ obtained as compared to both monounsaturated FA (MUFA) $(18.29 \pm 0.02 \%)$ and saturated FA (SAFA) $(24.25 \pm$ $4.76 \%$ ). The MUFA and PUFA, here produced in high yields were hexadecanoic acid (16:1) (15.25 $\pm 1.34 \%)$, octadecanoic acid $(18: 1 ; 3.05 \pm 1.36 \%)$, octadecadienoic acid $(18: 2 ; 24.46 \pm 1.91 \%)$, and octadecatrienoic acid $(18: 3,27.71 \pm 2.33 \%)$, which are also relevant FA for industrial production $[48,49]$. These yields were higher than those obtained without stress in Anabaena cylindrica, Aphanizomenon gracile and Nostoc muscorum [50]. Moreover, linoleic acid (C18:2 (n-6)) and $\alpha$-linolenic acid (C18:3 $(n-6)$ ) were the most abundant FA in the T. variabilis FAME profile. From the biological activity point of view, $\omega-3$ and $\omega-6$ FA are essential nutritional components that display important functions 
in the human metabolism [51], such as in the regulation of oxygen and electron transport and membrane fluidity $[52,53]$. Therefore, they can be effective in cardiac protection $[54,55]$ and cancer prevention [56-59], type 2 diabetes, inflammation and obesity [53,60,61]. These results suggest the possibility to use T. variabilis biomass as a low-cost source of PUFA for nutraceutical applications and to integrate the production of REPS with that of PUFA. This allows reducing operational costs and making the exploitation of the studied cyanobacterial strain economically more advantageous.

Table 1. Fatty acid methyl esters pattern (FAME $\% w / w)$ obtained from T. variabilis biomass.

\begin{tabular}{cccccc}
\hline & Fatty Acids & & \multicolumn{2}{c}{ \% FAME $w / w$} \\
\hline Systematic name & Common name & $\begin{array}{c}\text { Number of carbon } \\
\text { atoms:double bond(s) }\end{array}$ & Family & Mean * & SEM $^{\mathbf{1}}$ \\
\hline Decanoic acid & Capric acid & C10:0 & Saturated & 0.61 & 0.03 \\
Tetradecanoic acid & Myristic acid & C14:0 & Saturated & 0.70 & 0.01 \\
Hexadecenoic acid & Palmitoleic acid & C16:1 (n-7) & Monounsaturated & 15.25 & 1.34 \\
Hexadecadienoic acid & & C16:2 (n-4) & Polyunsaturated & 5.28 & 0.54 \\
Octadecanoic acid & Stearic acid & C18:0 & Saturated & 0.83 & 0.19 \\
Octadecenoic acid & Oleic acid & C18:1 (n-7) & Monounsaturated & 3.05 & 1.36 \\
Octadecadienoic acid & Linoleic acid & C18:2(n-6) & Polyunsaturated & 24.46 & 1.91 \\
Octadecatrienoic acid & $\alpha$-Linolenic acid & C18:3 (n-3) & Polyunsaturated & 27.71 & 2.33 \\
Eicosanoic acid & Arachidic acid & C20:0 & Saturated & 22.11 & 4.60 \\
SAFA & & & 24.25 & 4.76 \\
MUFA & & & 18.29 & 0.02 \\
PUFA & & & 57.45 & 4.77 \\
\hline
\end{tabular}

${ }^{1}$ SEM refers to standard error; ${ }^{*}$ Mean of three replicates.

\subsection{EPS Extraction and REPS Characterization}

The ability to synthesize relevant amounts of highly heterogeneous, hydrated and charged EPS plays critical roles in cyanobacterial cellular cohesion, protection and metabolic integrity. In response to water availability, EPS undergo striking changes in their rheological properties [62]. A first insight into their variable composition can be obtained by microscopic observations of cyanobacterial biomass after specific staining. Cytochemical characterization was performed using Alcian Blue $(A B)$ at two $\mathrm{pH}$ values (Figure $2 \mathrm{~B}, \mathrm{C}$ ). $\mathrm{AB}$ staining at $2.5 \mathrm{pH}$ revealed the presence of carboxylic groups in the EPS material adherent to T. variabilis cell surface (bound EPS), while $\mathrm{AB}$ at $0.5 \mathrm{pH}$ reacted with sulfated residues evidencing a lower amount in the released material, confirming what was previously observed for the same strain in our laboratory [12].

The obtained REPS after 20 days of growth were $465 \mathrm{mg} / \mathrm{gDW}$ and the plot of REPS production over growth is shown in Figure S1. Previous data on the same strain grown at bench-scale, without air mixing, showed lower REPS content, of about $86.7 \mathrm{mg} / \mathrm{gDW}$ [12]. Therefore, our data, in agreement with Pereira and colleagues [18], would evidence that the culture turbulence, due to the aeration, may facilitate the release of EPS from the cell surface and stimulate their synthesis. The REPS produced by T. variabilis in this study were about $46.5 \%$ of the dried biomass, a value comparable to that recently obtained from Trichocoleus sociatus (60\%) grown in an aerosol-based emerse photobioreactor (ePBR) to simulate this terrestrial cyanobacterium natural environment [14]. It has to be noted that that the proportion and composition of released and bound EPS can show high variability depending on external environmental/cultivation factors and on the strain itself. Indeed, a combination of drought and salt stress was successfully used to increase EPS production in Trichocoleus sociatus $[14,63]$. Previous data on the studied strain cultivated at smaller scale without any aeration showed a complex monosaccharide composition of its exopolysaccharides that were composed of ten different residues whose glucose and xylose were the most abundant and uronic acids, such as galacturonic acid and glucuronic acid, that contributed to their anionic nature and sticky character [12]. Figure 3A shows the RP-HPLC and the spectrophotometric data of the REPS solution demonstrating the absence of both hydrophobic compounds and chromophores. The low peptide or protein content was also 
confirmed by bicinchoninic acid (BCA) assay resulting in a protein concentration of $0.39 \pm 0.02 \mathrm{mg} / \mathrm{mL}$, corresponding to $3.6 \% w / w$ of REPS dry weight. Sugar content was assessed using phenol method, showing $10.2 \% w / w$ of REPS dry weight. Infrared spectroscopic analysis of the REPS powder, obtained after freeze-drying, was also performed (Figure 3B).
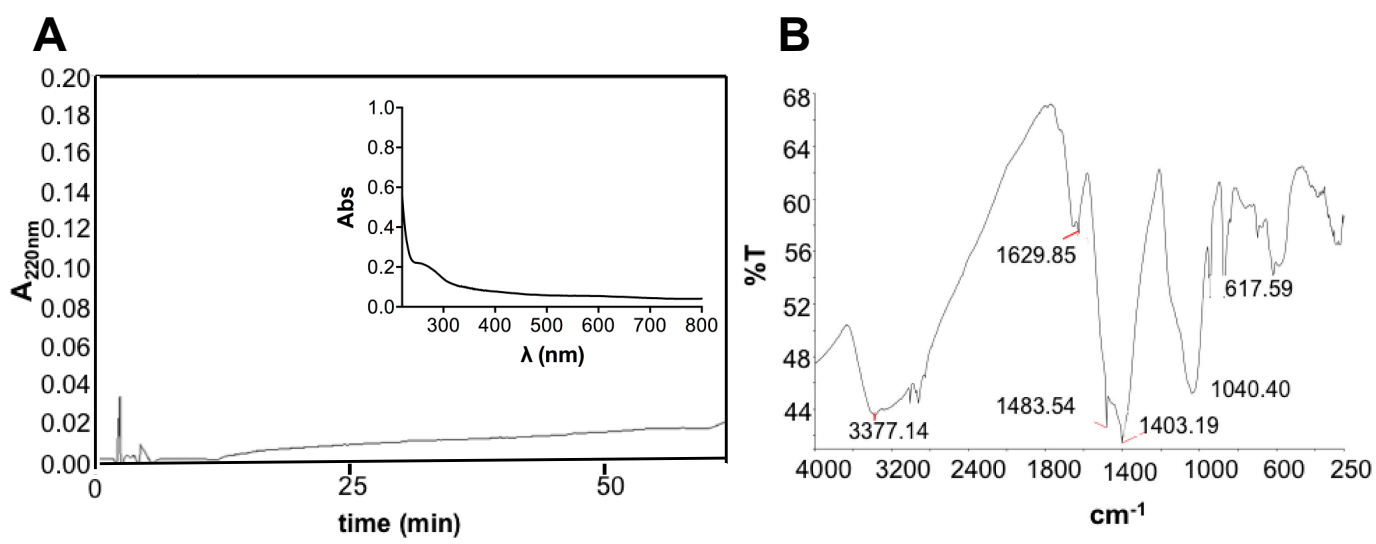

Figure 3. Characterization of REPS: (A) RP-HPLC chromatogram of REPS solution $(10 \mathrm{mg} / \mathrm{mL})$ using $\mathrm{C}_{18}$ column at $0.8 \mathrm{~mL} / \mathrm{min}$ flow rate and the following gradient: $0-5 \mathrm{~min}, 0 \%$; 5-50 $\mathrm{min}, 60 \%$; 50-55 $\mathrm{min}, 60 \%$; $55-60 \mathrm{~min}, 90 \%$; and $60-65 \mathrm{~min}, 90 \%$ of solvent $\mathrm{B}\left(80 \% v / v \mathrm{CH}_{3} \mathrm{CN}\right.$ and $0.1 \% v / v$ TFA). Inset: UV-vis absorption spectrum of REPS solution. (B) FT-IR spectrum of REPS showing signals within 4000 to $250 \mathrm{~cm}^{-1}$; the measurements were consistent among three replicates.

The FT-IR spectrum confirmed the presence of polysaccharides showing the presence of specific absorption bands. The observed bands were characteristic of carbohydrates $\left(1403 \mathrm{~cm}^{-1}\right.$ and $\left.1040 \mathrm{~cm}^{-1}\right)$ and polymeric substances $\left(3377 \mathrm{~cm}^{-1}\right.$ ) with $-\mathrm{OH},-\mathrm{COOH}$, phenolic and $-\mathrm{CH}_{2}$ groups [64-67]. In particular, the signal around $1040 \mathrm{~cm}^{-1}$ suggested the presence of carbohydrates with sulfur functional groups confirming what was observed after cytochemical staining in light microscopy. A peak around $3377 \mathrm{~cm}^{-1}$ was attributed to stretching vibration of hydroxyl groups, characteristic of $-\mathrm{OH}$ groups into polymeric substances. Furthermore, bands at $2915-2935 \mathrm{~cm}^{-1}$ were due to asymmetrical $\mathrm{C}-\mathrm{H}$ stretching vibration of aliphatic $\mathrm{CH}_{2}$-group [64,65]. Moreover, a band at $1629 \mathrm{~cm}^{-1}$ of the amide I region was observed, probably suggesting the presence of proteins [66]. The presence of several peaks at wavelengths lower than $1000 \mathrm{~cm}^{-1}$ may be due to several visible bands attributed to phenolic groups, phosphate functional groups and/or to the occurrence of possible linkages between monosaccharide units [68]. Furthermore, the presence of carboxylic groups suggests, when combined with the other observed bands, the presence of uronic acids (especially with sugar-characteristic bands) and of humic substances $\left(-\mathrm{CH}_{2}\right.$ and phenolic groups).

\subsection{REPS-Hy Synthesis and Characterization}

Generally, many polysaccharides are characterized by gelling property that was investigated by preparing several solutions at different concentrations of REPS and $\mathrm{pH}$ values. Although a gelation tendency was observed at $68.67 \mathrm{mg} / \mathrm{mL}$ in $\mathrm{H}_{2} \mathrm{O}$, the REPS gel was not stable. Therefore, hybrid hydrogels made of $8.0 \mathrm{mg} / \mathrm{mL}$ of REPS solution and $2 \%$ or $3 \%(w / v)$ of PEGDa $(6 \mathrm{kDa})$ were prepared by UV photo-polymerization, according to the schematic representation shown in Figure 4A. The presence of REPS was relevant for the gelation process, as shown in Figure 4B, wherein an unstable hydrogel obtained after photo-polymerization of a solution with $2 \%(w / v)$ of PEGDa without REPS (Figure 4B, top) is compared to a stable REPS-Hy with 3\% of PEGDa. The stability of the REPS-Hy in PBS was assessed both over two weeks at $4{ }^{\circ} \mathrm{C}$ and after $72 \mathrm{~h}$ at $37^{\circ} \mathrm{C}$ (Figure $4 \mathrm{~B}$, bottom); neither condition exhibited spontaneous hydrolysis. 


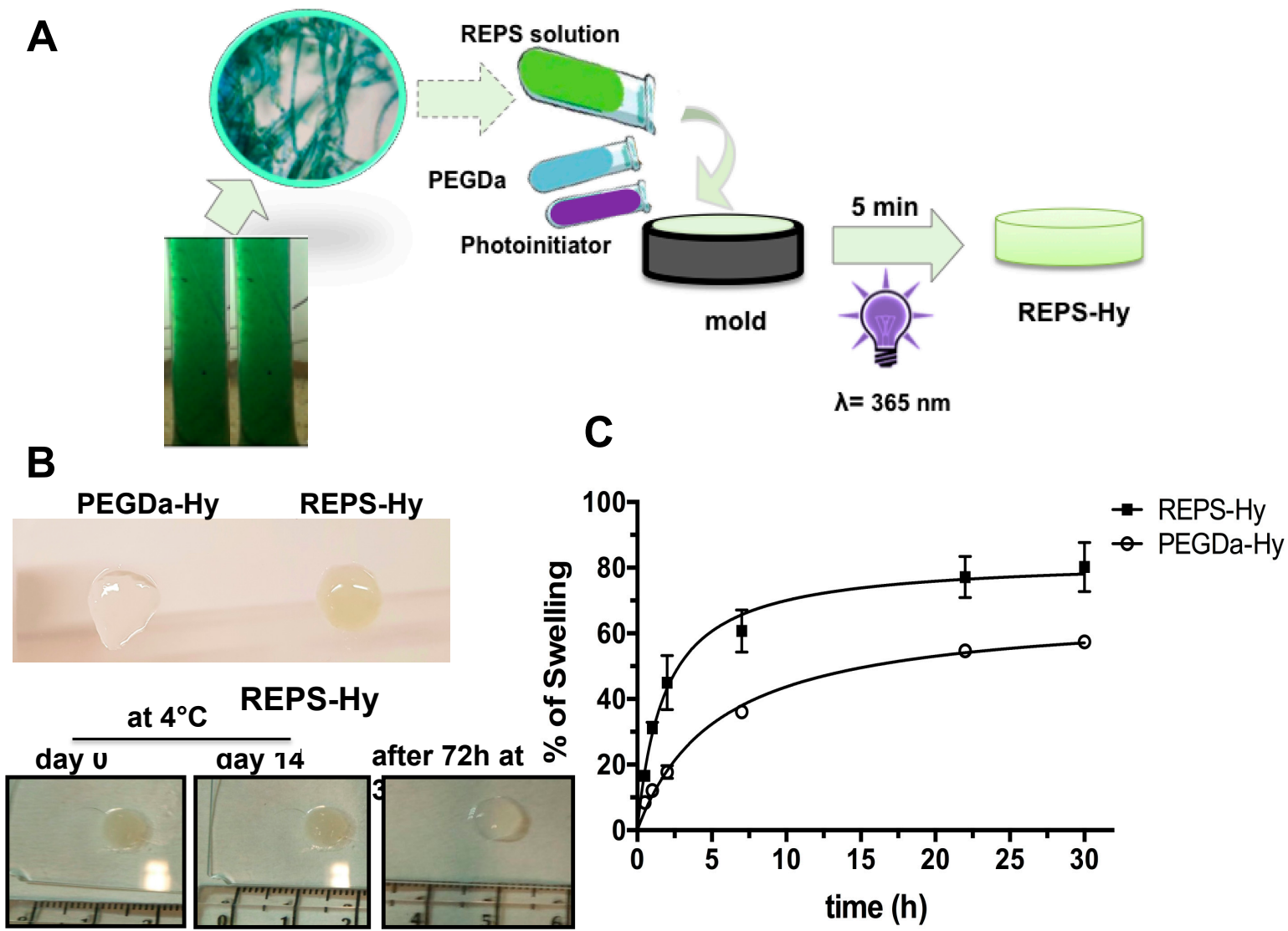

Figure 4. Synthesis and characterization of the REPS-Hy: (A) Schematic representation of REPS-Hy production: the gelling of the solution of $8.83 \mathrm{mg} / \mathrm{mL}$ of REPS with $3 \%$ of PEGDa $(6 \mathrm{kDa})(w / v)$, and $0.1 \%$ of Irgacure ${ }^{\circledR} 2959(w / v)$ was obtained after 5 min of UV light (365 nm) exposition. (B) Resistance of REPS-Hy to dehydration and spontaneous hydrolysis. Digital macro-photographs of: PEGDa-Hy with $2 \%$ of PEGDa without REPS and REPS-Hy with $\%$ of PEGDa $(w / v)$ (top); REPS-Hy with $3 \%$ of PEGDa-Hy $(w / v)$ at Day 0 and Day 14 after storage at $4{ }^{\circ} \mathrm{C}$, and after $72 \mathrm{~h}$ of incubation at $37^{\circ} \mathrm{C}$ in PBS (bottom). (C) Swelling rate curves of REPS-Hy and PEGDa-Hy in PBS up to the equilibrium swelling $(30 \mathrm{~h})$. The $\mathrm{R}^{2}$ of the hyperbolic fits of the swelling trend of REPS-Hy and PEGDa-Hy are 0.9284 and 0.9912 , respectively.

Moreover, REPS-Hy was resistant to dehydration and morphological changes were not detectable also after long incubation times (Figure 4B). The REPS-Hy degree of swelling was analyzed over time (Figure 4C) and compared to that of PEGDa-Hy, which was obtained using 3\% of PEGDa (6 kDa). The percentage of water-uptake (\%WU) at the "equilibrium swelling" ( $\left.\% \mathrm{~S}_{\mathrm{eq}}\right)$, was corresponding to $80.20 \pm 7.5 \%$ WU for REPS-Hy in PBS after $22 \mathrm{~h}$ of hydration. Moreover, the swelling of REPS-Hy was about $22.8 \pm 6.5 \%$ more than that observed for PEGDa-Hy. These results agree with the natural hydration properties of the EPS from cyanobacteria and such properties are crucial for the survival of these organisms. Important physiological properties, in fact, have been attributed to EPS including the physical barrier to the environment and the desiccation tolerance, as well as the subsequent rehydration $[62,69]$. These properties highly stabilize cells during long-term storage in the air-dried state [62]. The rheological properties of EPS are strictly related to their 3D supramolecular structure, which changes in response to environmental variables regulating the mass transfer and other biophysical properties that modulate cell activity. Therefore, the intrinsic EPS properties preserved in our REPS-Hy could be important in biomedical applications as well as in the emerging field of 3D-bioprinting. 
Rheological analysis of REPS-Hy and PEGDa-Hy (without REPS) reveals differences in the shear storage modulus $\left(\mathrm{G}^{\prime}\right)$ that are likely associated with additional crosslinking in the REPS-Hy (Figure 5). The plateau storage moduli of the REPS-Hy and PEGDa-Hy were $2778 \mathrm{~Pa}$ and $1785 \mathrm{~Pa}$, respectively (Figure 5A). The average shear loss modulus of the REPS-Hy was also higher than that of the PEGDa-Hy. This order of magnitude increase in shear loss modulus is likely attributed to higher viscosity associated with high molecular weight REPS macromolecules. The frequency and strain sweep rheological analysis confirms that the REPS-Hy and PEGDa-Hy both display similar viscoelastic behavior, notably that both show a uniform stress response to alternations in strain or frequency of oscillatory deformation (Figure 5B,C). Therefore, it is assumed that the REPS do not alter the polymer network structure beyond those attributes associated with the additional cross-linking and increased macromolecular chain length of the REPS.

A

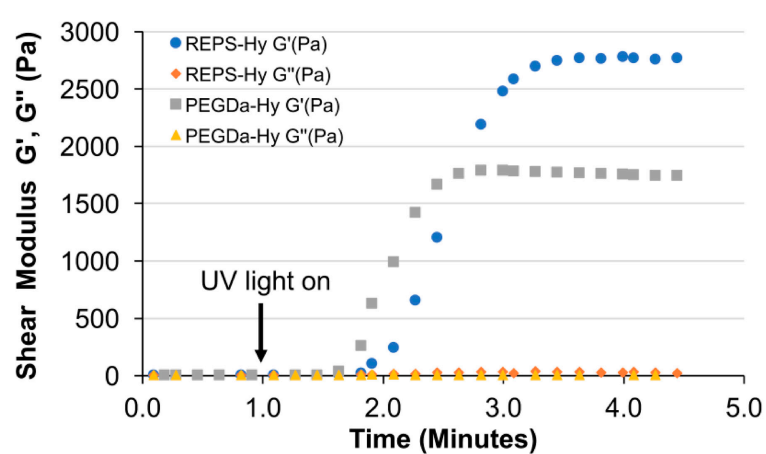

C
B

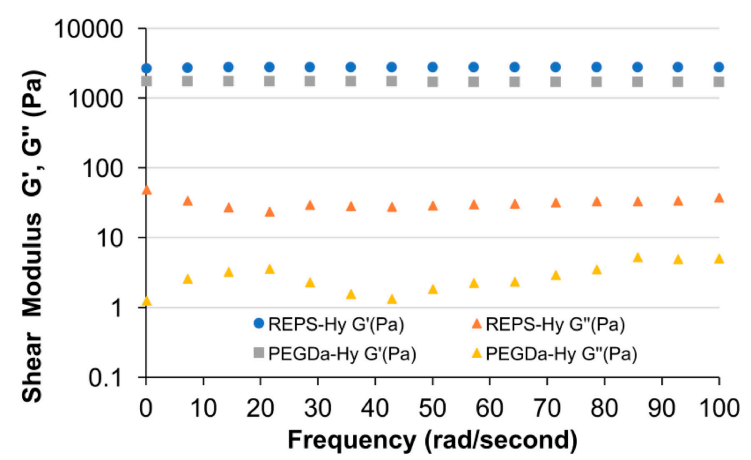

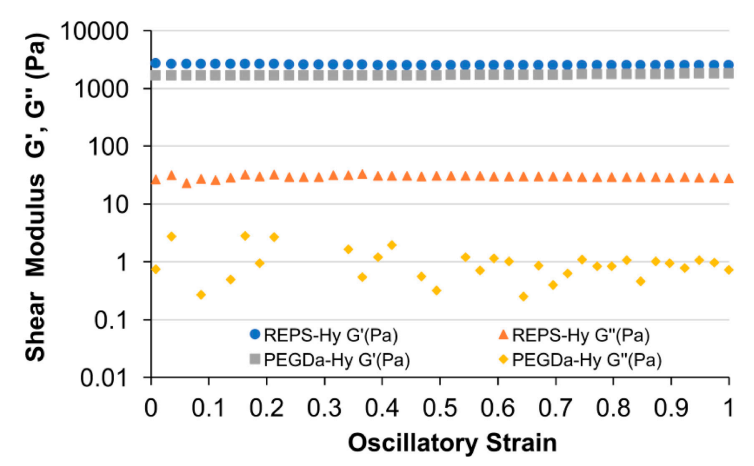

Figure 5. REPS improve hydrogel mechanical properties. Rheological measurement of REPS-Hy and PEGDa-Hy as evaluated by: time-sweep tests (A); frequency-sweep tests (B); and strain-sweep tests (C). The shear storage modulus $\left(\mathrm{G}^{\prime}\right)$ and shear loss modulus $\left(\mathrm{G}^{\prime \prime}\right)$ are shown for both hydrogels. (A) The time sweep data reveal an increase in $G^{\prime}$ upon the light-activated free-radical polymerization reaction of the REPS-Hy and PEGDa-Hy liquid precursors. The plateau G' of the REPS-Hy was 55\% higher as compared to the plateau $\mathrm{G}^{\prime}$ of the PEGDa-Hy, indicating that the REPS improves the elastic mechanical properties of the hydrogels. Following the chemical cross-linking of the hydrogels, the frequency-sweep (B) and strain-sweep (C) data confirmed a linear relationship between the shear modulus in the range of the applied frequency and strain.

\subsection{REPS-Hy as Enzyme-Carrier System}

REPS-Hy was studied as a potential enzyme-carrier system and the detoxification enzyme thiosulfate:cyanide sulfurtranferase (TST) was used as enzymatic model. The recombinant TST from Azotobacter vinelandii used herein is characterized by the presence of only one Cys residue, which is also the catalytic residue present in the active site. Figure 6A shows the scheme of its enzymatic 
activity. First, the TST activity was assessed in the presence and in the absence of REPS solution $\left(8.0 \mathrm{mg} / \mathrm{mL}\right.$ REPS, $8 \mathrm{mM} \mathrm{CaCl}_{2}$ in PBS) at room temperature at different times of incubation $(0 \mathrm{~min}$, $30 \mathrm{~min}$ and $20 \mathrm{~h}$ ) (Figure 6B). The REPS solution did not significantly affect the TST activity, even after many hours of incubation (Figure 6B). These results suggested us the possibility to embed the TST into REPS-Hy. The TST enzyme solution was mixed with REPS-Hy precursor solution and, after photo-polymerization, the TST activity was evaluated using the Sörbo assay at different incubation times in the presence of the substrates $\left(1,5,15,30\right.$ and $60 \mathrm{~min}$ ) at $37^{\circ} \mathrm{C}$ (Figure $6 \mathrm{C}$ ).
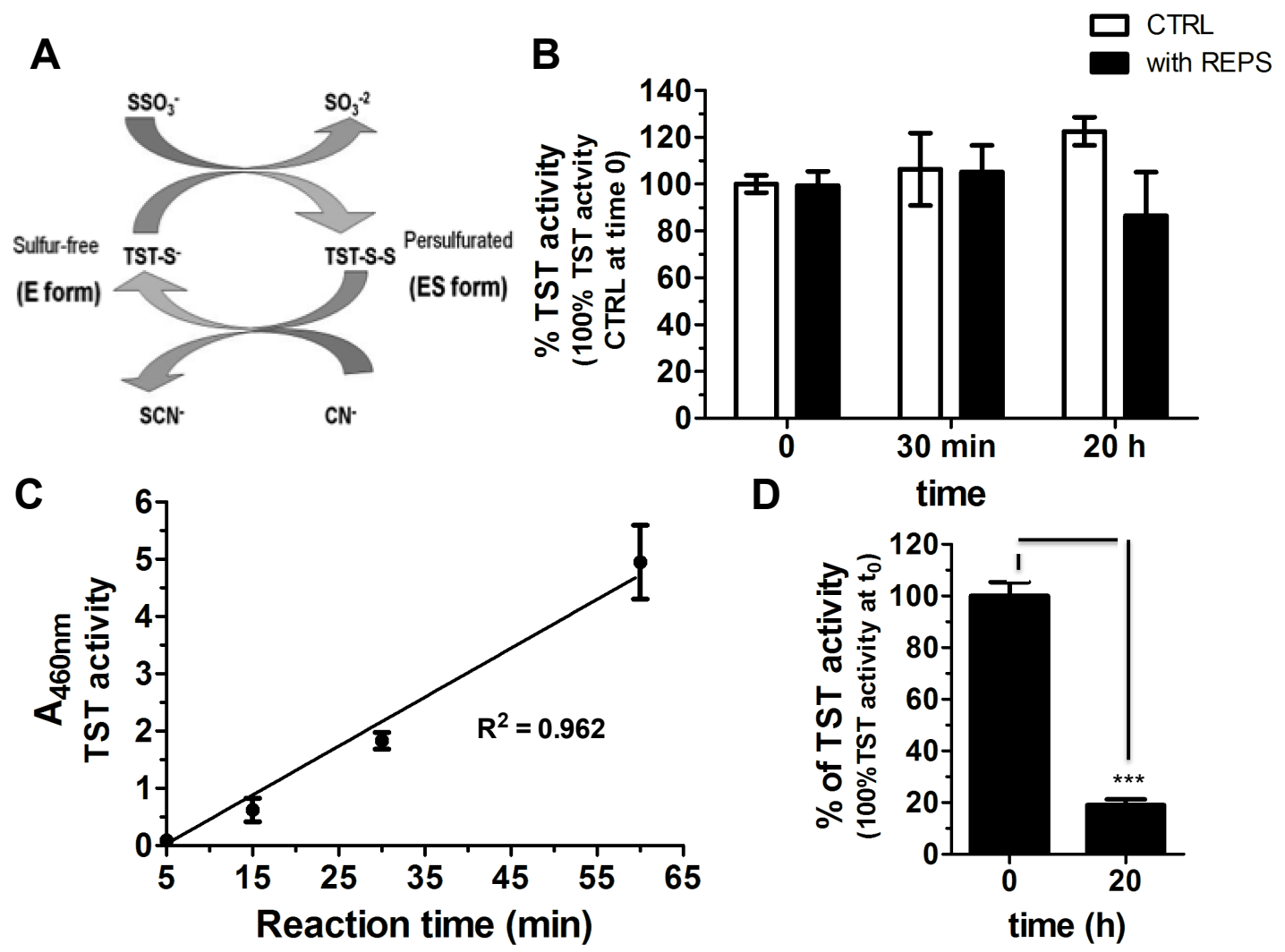

Figure 6. REPS-Hy as detoxification enzyme-encapsulating hydrogel: (A) Scheme of the catalytic cycle of the TST enzyme. (B) Percentage of TST activity over time of $3.12 \mu \mathrm{M}$ of TST in presence of $50 \mu \mathrm{L}$ of PBS (white) or of REPS solution ( $8 \mathrm{mg} / \mathrm{mL}$ of REPS and $8 \mathrm{mM}$ of $\mathrm{CaCl}_{2}$ in PBS, pH 7.4) (black) (100\% is the activity in PBS at time 0 ). The Sörbo assay was performed at $23^{\circ} \mathrm{C}$. (C) TST activity of TSTREPS-Hy at different incubation times $(5,15,30$ and $60 \mathrm{~min})$ at $37^{\circ} \mathrm{C}$. The reaction was stopped after incubation and the absorbance of the solutions measured after dilution. The line equation is $y=0.07611 \mathrm{x}$ and $\mathrm{R}^{2}$ is 0.9621. (D) TST activity of TSTREPS-Hy at time 0 and after $20 \mathrm{~h}$ at room temperature $\left(23^{\circ} \mathrm{C}\right)$ in $200 \mu \mathrm{L}$ of $50 \mathrm{mM}$ Tris-HCl, $\mathrm{pH} 8.0$, buffer $(100 \%$ is the TSTREPS-Hy activity at time 0$)$. ${ }^{* * *} p<0.001, n=3$ or 5 .

TSTREPS-Hy showed enzymatic activity (Figure 6D), although a statistically significant decrease of the enzymatic activity of the embedded TST in the gel with respect to the TST in solution was observed. This was probably due to both the photo-polymerization process and to the diffusion rates of the substrates and the final product.

A linear increase of the TST activity of the TSTREPS-Hy in a time-dependent manner was observed, likely owing to the diffusion phenomena in the gel (Figure 6C). Accordingly, the selected time to perform the activity assay of TSTREPS-Hy was $30 \mathrm{~min}$, which was a good compromise to have a detectable TST activity, minimizing the effect due to diffusion of the substrates and products in and out the gel and at least avoid the dilution for the measure of the absorbance. The enzymatic activity of TSTREPS-Hy was assessed over time (Figure 6D), and after $20 \mathrm{~h}$ of incubation into $200 \mu \mathrm{L}$ of $50 \mathrm{mM}$ 
Tris- $\mathrm{HCl}$ buffer, $\mathrm{pH} 8.0$, at $37^{\circ} \mathrm{C}$ only the $20 \%$ of the TST activity was recovered. The decrease of the enzymatic activity could be due to the release of the enzyme from the gel considering that the REPS solution did not induce a statistically significant inhibition of the enzymatic activity. The RP-HPLC analysis of the soluble fraction was performed, but unfortunately the TST release was not detectable for the overlapping of the retention times of TST peak with PEGDa-derivative molecules that were released from the gel (Figure S2). These preliminary results suggest the possibility to use the REPS-Hy as TST carrier system for the cyanide detoxification. A rapidly growing class of modern therapeutics is constituted by proteins and peptides, which often show a better efficiency than small drugs for the therapy and diagnosis of serious and deadly diseases. However, their administration is often difficult due to the loss of the native structure and rapid cleavage in the liver or other body tissues. Their instability could be diminished by biocompatible and biodegradable hydrogels useful as carriers able to improve their bioavailability and to provide other routes of administration [70]. Several proteins including insulin, growth hormones, and interferons at other proteins have been already encapsulated in microbial exopolysaccharide hydrogel particles [71-74] and the improving their administration has been demonstrated. In this context, the results herein proved activity of the detoxification enzyme either in the presence of REPS solution from T. variabilis or into REPS-Hy. They suggest the possibility to use EPS for the production of hydrogel carrier systems of enzymes characterized by the presence of cysteine at the catalytic site, although other experiments, using different enzymes, are necessary to support this hypothesis. Moreover, the enzyme-REPS-Hy could represent a good opportunity to combine the EPS natural properties, such as antibacterial, anti-oxidative and anti-inflammatory properties [75], with a specific enzymatic activity.

\subsection{REPSHy as Stem Cell Carrier for Tissue Engineering}

The biocompatibility of REPS-Hy was also evaluated by analysis of the cell adhesion of human mesenchymal stem cells (hMSCs) seeded onto REPS-Hy and cultured for two weeks in the presence of DMEM medium. Figure 7 shows the confocal laser scanning micrographs of hMSCs after two weeks of growing on REPS-Hy.

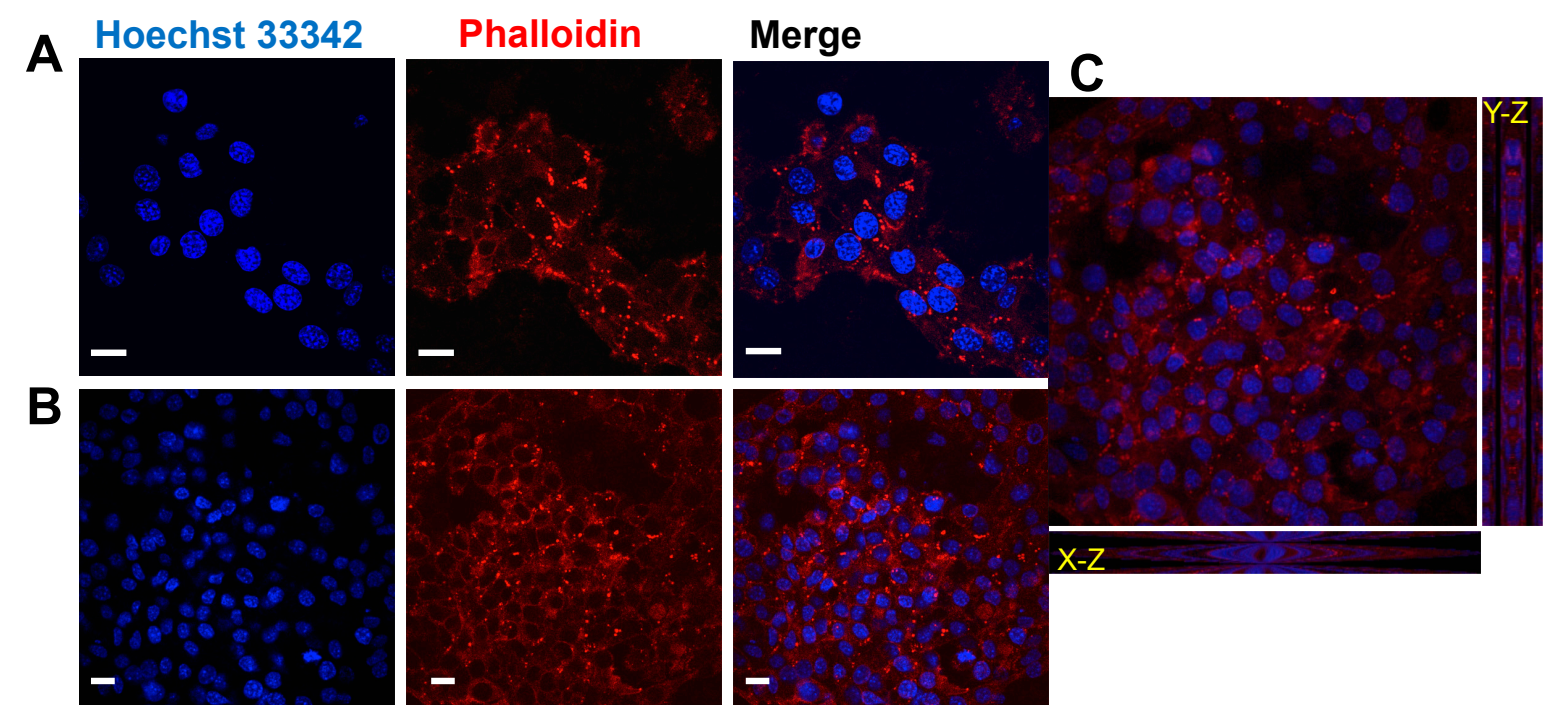

Figure 7. hMSCs cultures using REPS-Hy as scaffold. Confocal laser scanning micrographs of hMSC s cultured for two weeks on REPS-Hy: (A) at 60× magnificantion; (B) at $40 \times$ magnification; and $(\mathrm{C})$ micrographs with $\mathrm{Y}-\mathrm{Z}$ and $\mathrm{X}-\mathrm{Z}$ projections. F-actin was stained with Alexa-fluor 568 phalloidin-conjugate (in red) and the nuclei were stained using Hoechst 33342 (in blue). Scale bars $=10 \mu \mathrm{m}$. 
The nuclei were stained with Hoechst 33342 and F-actin with Alexa-fluor 568 phalloidin-conjugate and it was notably the presence of multicellular networks. The presence of many cells with elongated morphology demonstrated a good adhesion of the hMSCs to the material and not cytotoxicity. Moreover, hMSCs were embedded into the REPS-Hy during the photo-polymerization, thus producing a 3D-stem cell culture system. The scheme of the 3D-stem cell culture system preparation is shown in Figure 8A. The cell viability was evaluated after zero and three days of growth (Figure 8B,C) and $82.43 \pm 0.01 \%$ cell proliferation was observed.

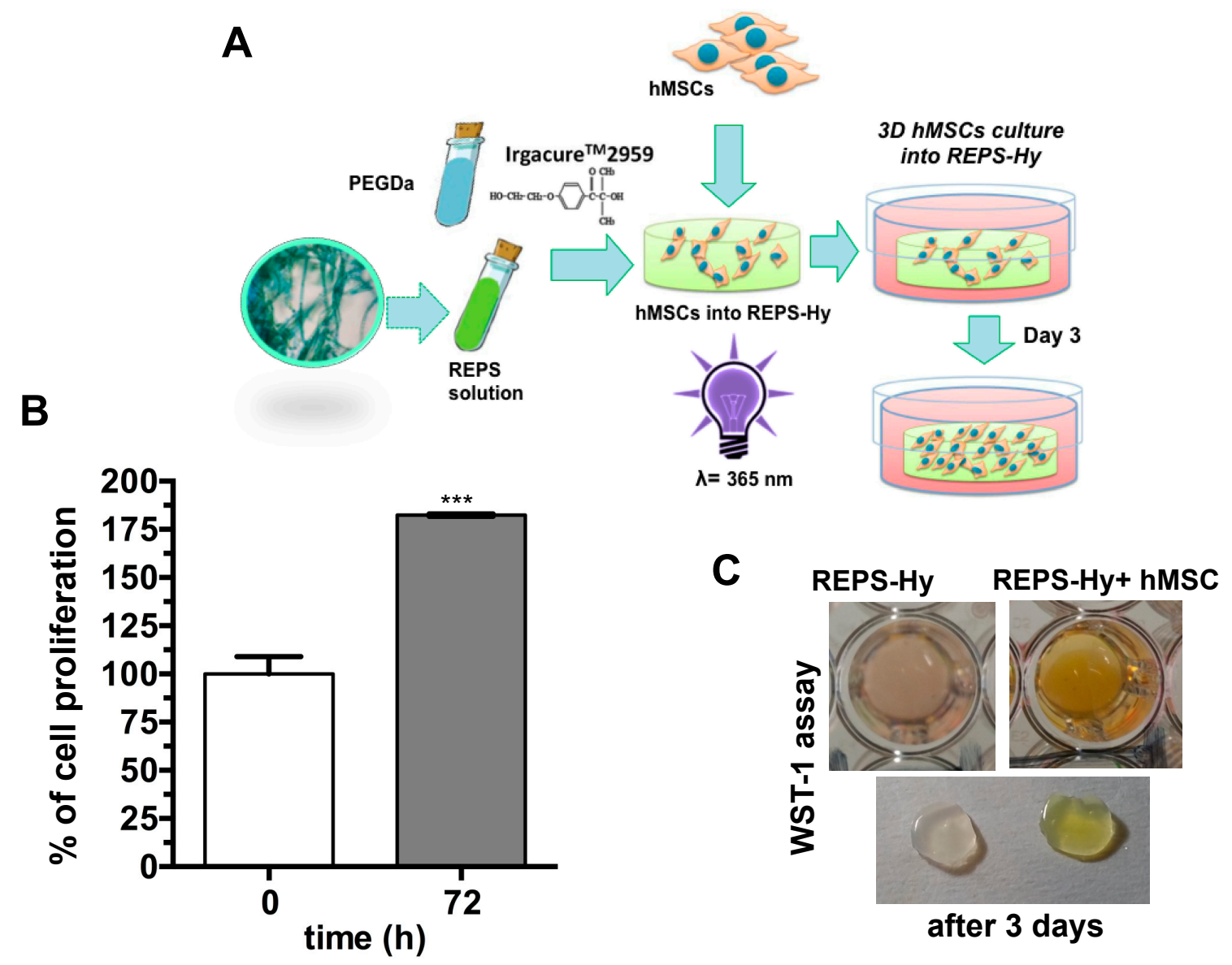

Figure 8. REPS-Hy as stem cell-carrier system: (A) Schematic representation of the production of REPS-Hy scaffolds for 3D hMSC cultures. (B) Cell viability of hMSCs embedded into the REPS-Hy, immediately after photo-polymerization (time 0$)$ and after $72 \mathrm{~h}$ of $3 \mathrm{D}$ cell culture $(100 \%$ is the cell viability at time 0 ). (C) Digital macro-photographs of REPS-Hy with and without embedded hMSCs after colorimetric WST-1 cell viability assay. ${ }^{* * *} p<0.001$.

These preliminary results confirm the cytocompatibility of the REPS-Hy and open the way to produce new 3D-hybrid scaffolds for tissue engineering, where the physiological role of the EPS to protect the cell from unfavorable stress and to increase the cell-cell interaction [75] could be exploited for improving the tissue formation.

Moreover, an emerging technological and biomedical field is represented by 3D-bioprinting [76,77] of tissues and organs using stem cells and biomaterials. Photo-polymerizable hydrogels represent optimal biomaterials for this new technology for generating injectable cell/drug carrier systems.

The preparation of an appropriate bio-ink represents in 3D-bioprinting one of the main challenges. The printable biomaterials should have optimal structural and mechanical properties to drive the fate of the stem cell, while also protecting the cells from damage during printing. The peculiar intrinsic characteristics of the EPS such as the high water-uptake, dehydration resistance and the 
radical scavenging could be relevant properties of a bio-ink in reduce the cellular damage during the bio-printing process. Indeed, EPS can naturally inhibit the desiccation stress of the cyanobacteria, reducing the damage to cell membranes, nucleic acids and proteins induced by reactive oxygen species (ROS) under high light and UV irradiation [78]. Accordingly, with the radical scavenging property of the cyanobacterial EPS, the REPS presence in the hydrogel could reduce oxidative damages due to photo-polymerization process for 3D-bioprinting technologies.

\section{Materials and Methods}

\subsection{Trichormus Variabilis Biomass Cultivation}

A strain of the heterocytous cyanobacterium T. variabilis (Kützing ex Bornet \& Flahault) Komárek \& Anagnostidis (VRUC168) was isolated from microphytobenthos of a Mediterranean shallow coastal lagoon (Cabras lagoon, Sardinia, Italy) [11] and maintained in standard Blue Green Medium (BG11) [79] at $18-20^{\circ} \mathrm{C}$, irradiance of $30 \mu \mathrm{mol}$ photons $\mathrm{m}^{-2} \mathrm{~s}^{-1}$ and $12: 12 \mathrm{hs} \mathrm{L} / \mathrm{D}$ cycle. A polyphasic approach was used for strain circumscription elsewhere [12]. The stock culture was acclimated at higher irradiance and temperature conditions $\left(80 \mu \mathrm{mol}\right.$ photons $\left.\mathrm{m}^{-2} \mathrm{~s}^{-1}, 25^{\circ} \mathrm{C}\right)$ and used as inoculum for biomass production. Three culture replicates were set up in $400 \mathrm{~mL}$ flasks in batch and the growth curves recorded by measuring the optical density (OD) at $730 \mathrm{~nm}$ (BECKMAN DU-65 spectrophotometer, BECKMAN COULTER, High Wycombe, UK) and the dry weight $\left(\mathrm{T}=60^{\circ} \mathrm{C}\right)$ at $24 \mathrm{~h}$ intervals. At the stationary phase, Day 35, each culture was used as inoculum to mass cultivate T. variabilis in three low-cost polyethylene bags (PBRs), of $10 \mathrm{~L}$ each. BG11 medium was supplied only at the beginning of the growth experiments. The PBRs were kept, at the optimized growth conditions with air mixing, in a growth cabinet equipped with white fluorescent lamps (OSRAM L 30w/956, Munich, Germany) and thermostated $\left(25^{\circ} \mathrm{C}\right)$. Subsamples $(1 \mathrm{~mL}$ for OD and $5 \mathrm{~mL}$ for dry weight) of each PBR cultures were taken in triplicate every $48 \mathrm{~h}$ and the growth estimated as above. The daily biomass productivity was calculated by dividing the difference between the dry weights estimated at the end and at the beginning of the experiments by the experiment duration (days) [80]. Biomass separation was carried out at the stationary phase (Day 20) when air mixing was stopped and biomass settled at the bottom of the PBRs and the total biomass yield was evaluated after centrifuging $(5000 \times g$ for $20 \mathrm{~min}$; Heraeus SEPATECH, Megafuge 1.0, Thermo Fisher Scientific, Waltham, MA, USA) and freeze-drying.

Light microscopy observations of culture samples at the stationary phase were conducted after staining for $10 \mathrm{~min}$ using Alcian Blue (AB) $1 \%$, in $\mathrm{HCl} 0.5 \mathrm{~N}$ (pH 0.5), specific for sulfated polysaccharidic residues present in the REPS or in $3 \%$ acetic acid ( $\mathrm{pH} 2.5$ ) specific for carboxylic moieties. A light microscope (ZEISS Axioskop, CARL ZEISS, Jena, Germany) equipped with differential interference was used and the micrographs were acquired using a digital camera Coolpix995 (Nikon, Tokyo, Japan).

\subsection{Extraction of REPS}

Released-EPS fraction was obtained according to Ahmed and colleagues procedure [81]. The culture solutions from the PBRs were centrifuged (5000 $\times g$ for $20 \mathrm{~min}$ ) and the supernatants containing REPS were separated from pellets. The following steps were designed and adapted to the scaling up of REPS production. Thus, the supernatants were evaporated and the REPS concentrated using a Rotavapor Buchi WaterBath B- 480 at $45^{\circ} \mathrm{C}$. The concentrated supernatant was precipitated in $96 \%$ cold ethanol and the REPS fraction was obtained. The fraction was dialyzed against bi-distilled water at $4{ }^{\circ} \mathrm{C}$ for 2-3 days using a dialysis membrane with a cut-off of $18 \mathrm{kDa}$ (Spectrum Laboratories, Inc., Breda, Netherlands), and then freeze-dried and stored at $-20{ }^{\circ} \mathrm{C}$ for further analysis.

\subsection{REPS Characterization}

Ten milligrams of freeze-dried REPS were dissolved in $1 \mathrm{~mL}$ MilliQ water and total sugar content determined by the phenol-sulfuric acid method, using glucose as standard [82] (Figure S3). Total 
protein concentration was also assessed using BCA colorimetric assay (Sigma-Aldrich, Milan, Italy) and bovine albumin (BSA) as standard protein for calibration curve.

The RP-HPLC analysis of the REPS solutions was performed using LC-10AVP equipment (Shimadzu, Milan, Italy), $0.1 \% v / v$ trifluoroacetic acid as solvent $\mathrm{A}$ and $80 \% v / v$ acetonitrile and $0.1 \% v / v$ trifluoroacetic acid as solvent $\mathrm{B}$. The analyses were performed using a $\mathrm{C}_{18}$ column (CPS Analitica, $150 \mathrm{~mm} \times 4.6 \mathrm{~mm}, 5 \mu \mathrm{m}$ ), a loop of $20 \mu \mathrm{L}$, flow of $0.8 \mathrm{~mL} / \mathrm{min}$ and the following solvent B gradient: 0-5 min, 0\%; 5-50 $\mathrm{min}, 60 \%$; 50-55 $\mathrm{min}, 60 \%$; 55-60 $\mathrm{min}, 90 \%$; and $60-65 \mathrm{~min}, 90 \%$. The elution was monitored at $220 \mathrm{~nm}$ by a UV detector (Shimadzu, Milan, Italy).

FT-IR Spectroscopy was used for chemical analysis of freeze-dried REPS material, using a Perkin Elmer Spectrum 100 (PerkinElmer Inc., Paris, France). Spectra were acquired in the range $4000-250 \mathrm{~cm}^{-1}$, by averaging 32 scans at a resolution of $4 \mathrm{~cm}^{-1}$, using CsI cells. Data were processed using Spectrum 6.3.5 software (PerkinElmer Inc., Paris, France).

\subsection{FAME Extraction and Characterization}

FAME extraction from residual biomass and in situ trans-esterification, were carried out as previously described $[13,83]$. Briefly, the biomass after EPS extraction, was resuspended in a methanol and sulfuric acid $(v / v 15: 1)$ mixture for $6 \mathrm{~h}$ at $60^{\circ} \mathrm{C}$. After filtration, hexane was used to separate the FAME fraction. FAMEs content was estimated as the percentage of esterified lipids per dry biomass (grams). The FAME profile was determined using a gas chromatograph-mass spectrometry (Gas chromatograph GC-2010 Plus mass spectrometer GCMS-QP2010 Ultra; Shimadzu Corp., Kyoto, Japan). Eight microliters of each sample were injected into the column (SLB-5ms Fused Silica Capillary Column; $30 \mathrm{~m} \times 0.25 \mathrm{~mm} \times 0.25 \mu \mathrm{m}$ film thickness) with a temperature program starting from $170{ }^{\circ} \mathrm{C}$, increasing of $3{ }^{\circ} \mathrm{C} / \mathrm{min}$ to $240{ }^{\circ} \mathrm{C}$ final, hold for $20 \mathrm{~min}$. Split ratio was $1: 80$ and injection temperature $280{ }^{\circ} \mathrm{C}$, helium was used as carrier gas. The run time for every single sample was $35 \mathrm{~min}$. The identification of FA was performed by comparing the obtained mass spectra with NIST Mass Spectral Data Base (http://webbook.nist.gov/chemistry/). Total lipid concentration refers to the sum of total FAMEs.

\subsection{REPS-Hydrogel Preparation}

PEGDa 6 kDa MW (Sigma-Aldrich, Milan, Italy) and REPS solution were used for synthesizing highly cross-linked hydrogels (REPS-Hy). REPS $(8.83 \mathrm{mg} / \mathrm{mL}), 10 \mathrm{mM} \mathrm{CaCl}_{2}$ and 2 or $3 \%(w / v)$ of PEGDa were solubilized in PBS, pH 7.4. The free-radical photo-polymerization of the hydrogels was achieved by addition of $0.1 \%(w / v)$ Irgacure ${ }^{\circledR} 2959$ (Ciba Specialty Chemicals, Basel, Switzerland) to the precursor solution, followed by 5 min exposure to long-wave UV light ( $365 \mathrm{~nm}, 4-5 \mathrm{~mW} / \mathrm{cm}^{2}$ ). Finally, REPS-Hys were washed with sterile PBS solution to remove non-polymerized material.

\subsection{REPS-Hy Characterization}

\subsubsection{Rheological Analyses of REPS-Hy}

The mechanical properties of the REPS-Hy were measured using oscillatory, strain-rate controlled rheometry. The shear storage modulus $\left(\mathrm{G}^{\prime}\right)$ of the hydrogels was determined by applying oscillatory strain and measuring the shear response, using a TA Instruments AR-G2 rheometer (ARES, TA Instruments, New Castle, DE, USA) equipped with a 20-mm parallel-plate geometry adapted with an ultraviolet (UV) light-curing assembly. The sample $(200 \mu \mathrm{L})$ of the liquid hydrogel precursor was pipetted onto the transparent lower plate, and the upper plate was lowered until it reached a gap of $\sim 600 \mu \mathrm{m}$. For hydrogel curing, the precursor was exposed from underneath the geometry to long-wave UV light $\left(365 \mathrm{~nm}, 5 \mathrm{~mW} / \mathrm{cm}^{2}\right)$. Dynamic time sweeps were performed at $25^{\circ} \mathrm{C}, 2 \%$ sinusoidal strain, and $3 \mathrm{rad} / \mathrm{s}$ constant frequency, while continuously monitoring the shear response of the materials before, during and after light-activated polymerization (in situ rheometry). The measurements were carried out for one minute without UV, followed by UV light activation until after the maximum value of G' was reached (approximately $5 \mathrm{~min}$ ). Frequency sweep measurements were performed on the 
hydrogels, whereby constant $2 \%$ strain at an oscillation frequency of $0.1-100 \mathrm{rad} / \mathrm{s}$ was applied while measuring the shear response. Strain sweep measurements were performed on the hydrogels whereby the oscillation frequency was held constant at $3 \mathrm{rad} / \mathrm{s}$ and strain was varied from $1 \%$ to $100 \%$, while measuring the shear response. The sample rheology measurements were performed on two replicates for each treatment.

\subsubsection{Swelling Analysis of REPS-Hy}

Swelling behavior of REPS-Hydrogel was investigated over $24 \mathrm{~h}$, at room temperature, until equilibrium swelling as described elsewhere [84,85]. Briefly, three replicas of REPS-Hy and PEGDa-Hy (used as control) were weighted immediately after photo-polymerization and placed into a well with $500 \mu \mathrm{L}$ of PBS and weighed at different times: 1, 2, 6, 24 and $30 \mathrm{~h}$. The degree of swelling, corresponding to the percentage of water uptake (WU), was calculated following Equation (1):

$$
\% \mathrm{WU}=\left(\mathrm{W}_{\mathrm{t}}-\mathrm{W}_{0}\right) / \mathrm{W}_{0} \times 100
$$

where $\mathrm{W}_{\mathrm{t}}$ is the mass of the swollen hydrogel at time $\mathrm{t}$, and $\mathrm{W}_{0}$ is the mass after gel-polymerization.

\subsection{Detoxification Enzyme Synthesis and Encapsulation into the REPS-Hy}

Recombinant thiosulfate:cyanide sulfurtransferase (TST, rhodanese EC.2.8.1.1) from Azotobacter vinelandii was produced and purified as previously described [86,87]. TST activity of the enzyme was tested using the Sörbo assay [88] obtaining an enzymatic activity of $64.06 \mathrm{U} / \mathrm{mg}$. Briefly, the Sörbo assay was performed as follow: the recombinant TST enzyme was incubated at $37^{\circ} \mathrm{C}$ in a reaction mixture ( $650 \mu \mathrm{L}$ of $58 \mathrm{mM} \mathrm{KCN}$ and $58 \mathrm{mM}$ sodium thiosulfate in $50 \mathrm{mM}$ Tris- $\mathrm{HCl}$ buffer, $\mathrm{pH} 8.0)$. The reaction was stopped after $1 \mathrm{~min}$ by adding $100 \mu \mathrm{L}$ of $15 \%$ formaldehyde and addition of $250 \mu \mathrm{L}$ Sörbo reagent ( $100 \mathrm{~g}$ of ferric nitrate and $200 \mathrm{~mL}$ of $65 \%$ nitric acid per $1500 \mathrm{~mL}$ ). The product was monitored reading the absorbance at $460 \mathrm{~nm}$. The Sörbo assay for evaluating the TST activity in the presence and in the absence of REPS solution $\left(8 \mathrm{mg} / \mathrm{mL} \mathrm{REPS,} 8 \mathrm{mM} \mathrm{CaCl}_{2}\right.$ in PBS) was performed at $23^{\circ} \mathrm{C}$ after $1 \mathrm{~min}$ of incubation. Then, $10.08 \mu \mathrm{M}$ of TST in $60 \mu \mathrm{L}$ of REPS-Hy precursor solution (solution with $6.67 \mathrm{mg} / \mathrm{mL}$ REPS, 3\% $w / v$ PEGDa, 1.6\% v/v Irgacure ${ }^{\circledR} 2959$ and PBS) was photo-polymerized for $5 \mathrm{~min}$ under UV light at $365 \mathrm{~nm}$. The solution was photo-polymerized into a teflon mold $(50 \mathrm{~mm}$ inner diameter) and the TST activity of the TSTREPS-Hy was assessed at different times of incubation $(1,5,15,30$ and $60 \mathrm{~min})$ of the gel at $37^{\circ} \mathrm{C}$ with $58 \mathrm{mM} \mathrm{KCN}$ and $58 \mathrm{mM}$ sodium thiosulfate in $50 \mathrm{mM}$ Tris- $\mathrm{HCl}$ buffer, $\mathrm{pH}$ 8.0, the reaction was stopped by addition of formaldehyde and Sörbo reagent and the absorbance evaluated at $460 \mathrm{~nm}$.

\subsection{Stem Cell Viability in 2D and 3D Cell Growth Systems}

Human cardiac resident Mesenchymal Stem Cells (hMSC) line expressing stem cell marker $\mathrm{Sca}^{-} 1^{+} \mathrm{Lin}^{-}$, was obtained as previously described [37,89]. Briefly, the cell line was obtained from cells isolated from human auricular biopsies made during the course of coronary artery bypass surgery of patients undergoing cardiac surgery after signing a written consent form for the research study, according to a joint protocol approved by the Ethic Committees of Ospedale Maggiore della Carita, Novara and University Hospital Le Molinette, Turin 2011. The cells were cultured in Dulbecco's modified Eagle medium (DMEM) (Gibco, Monza, Italy) supplemented with $10 \%$ of fetal bovine serum (FBS) $(v / v)$ (Gibco, Monza, Italy), $2 \mathrm{mM}$ L-Glutamine (Sigma-Aldrich, Milan, Italy), $100 \mathrm{U} / \mathrm{mL}$ penicillin and $100 \mu \mathrm{g} / \mathrm{mL}$ streptomycin (Sigma-Aldrich, Milan, Italy) (hereafter referred to as "complete medium") at $37{ }^{\circ} \mathrm{C}$ and with $5 \% \mathrm{CO}_{2}$. After trypsinization, the cells were seeded onto the surface of the polymerized REPS-Hy (at a density of $1 \times 10^{4}$ cells $/ \mathrm{cm}^{2}$ ), or embedded into the hydrogels by re-suspending them in the REPS-Hy precursor solution prior the photo-polymerization procedure (at a density of $0.417 \times 10^{6}$ cells $/ \mathrm{mL}$ ). The cell-seeded hydrogels and the cell-embedded ones were cultivated in $1 \mathrm{~mL}$ of complete medium in 24-multiwell plates for 14 
and 3 days, respectively. The cell viability was quantified by WST-1 colorimetric assay [90]. Briefly, WST-1 assay (4-[3-(4-lodophenyl)-2-(4-nitrophenyl)-2H-5-tetrazolio]-1,3-benzene disulfonate) (Roche Diagnostics, Sigma Aldrich, Milan, Italy) was performed by incubating the hydrogel samples for $3 \mathrm{~h}$ in complete DMEM (without phenol-red) in the presence of $5 \%(v / v)$ cell proliferation Reagent WST-1 at $37^{\circ} \mathrm{C}$ and in $5 \% \mathrm{CO}_{2}$. The absorbance of the medium was evaluated using iMark ${ }^{\mathrm{TM}}$ Microplate Reader (Bio-Rad, Milan, Italy) at a $450 \mathrm{~nm}$ wavelength.

\subsection{Immunofluorescence Microscopy Analyses}

hMSC phenotype of the cells seeded and cultured on REPS-Hy was analyzed by immunofluorescence microscopy. Gels were washed in PBS, fixed in $4 \%$ paraformaldehyde (PFA) (Sigma-Aldrich, Milan, Italy) in PBS for $30 \mathrm{~min}$ at room temperature. After that, the cells were permeabilized with $0.3 \%$ Triton X-100 (Sigma-Aldrich, Milan, Italy) for 5 min and maintained in a blocking buffer $(10 \% v / v$ FBS, $0.1 \% v / v$ Triton X-100 and $1 \% w / v$ glycine in PBS) overnight at $4{ }^{\circ} \mathrm{C}$. Hydrogels were incubated with F-actin 488-Alexa fluorochrome-conjugated phalloidin (Life Technologies, Milan, Italy). Nuclei were stained with 1:25,000 w/v Hoechst 33342 (Sigma-Aldrich, Milan, Italy) in PBS. Hydrogels were stored at $4{ }^{\circ} \mathrm{C}$ in $20 \mathrm{mM}$ Gly PBS under dark conditions. Confocal microscopy was performed using Nikon Eclipse Ti (Nikon, Tokyo, Japan) and the signal was detected using EZ C.1 software (Nikon, Tokyo, Japan).

\subsection{Statistical Analysis}

GraphPad Prism version 6.0 program (GraphPad Software, San Diego, CA, USA) was used for statistical analysis. Three or five independent experiments were performed for each result and the analysis of the variables was made using ANOVA One-way test or the one-tailed Student's $t$-test. A $p$-value of $<0.05$ was considered to be statistically significant. Standard deviations (SD) or the standard errors (SEM) of the mean were calculated and reported for each sample.

\section{Conclusions}

In this work, efficient biomass production by a native brackish strain of the cyanobacterium T. variabilis was obtained in a low-cost PBR to optimize a sequential extraction protocol for the EPS and PUFA production. This strain showed suitable productivity in the $10 \mathrm{~L}$ bags used, after 20 days without nutrient repletion, allowing us to collect sufficient biomass to be exploited for the target application. The potential to obtain an integrated and economically advantageous production of nutraceuticals and biomaterials was demonstrated. REPS fraction was characterized and used for producing a new photo-polymerizable hybrid-hydrogel. REPS-Hy was characterized for its physical, mechanical and biological properties and for its ability to embed detoxification enzymes with catalytic cysteine residues, such as TST. The results herein presented show the possibility to fabricate new functional non-cytotoxic hydrogels with enzymatic activity for therapeutic and environmental applications. The presence of carboxyl groups in the REPS could also help to produce hydrogels that exhibit $\mathrm{pH}$-sensitive swelling behavior that could increase their pore size at basic $\mathrm{pHs}$ and allow the protein release from the matrix in the intestinal environment, significantly improving the absorption of the protein-drugs, as already demonstrated for insulin embedding hydrogels [91,92]. Moreover, in a proof-of-concept experiment, REPS-Hy was also used for fabricating 3D-cell embedding hydrogels, demonstrating the feasibility for the production of cell-carrier systems in cell therapy and of photo-printable bio-inks for tissue engineering applications. This is a first and preliminary study, which combines the multiple inexpensive production of cyanobacteria nutraceutical products with that of photo-polymerizable hydrogels for enzyme- and stem cell-carrier systems. Although the data reported suggest a good potential feasibility, further experiments are necessary to demonstrate the in vivo applicability.

Supplementary Materials: The following are available online at http:/ / www.mdpi.com/1660-3397/16/9/298/s1, Figure S1: REPS production over time; Figure S2: RP-HPLC analysis of the TST solution and of the fraction released from the REPS-Hy; Figure S3: Biochemical analysis of REPS. 
Author Contributions: Conceptualization, S.M. and R.C.; Methodology, S.M., M.C., E.B., S.A. and R.C.; Software, S.S., E.B. and M.C.; Formal Analysis, E.B., S.M., S.A., M.C., S.S., D.S. and R.C.; Investigation, S.M., E.B., M.C. and R.C.; Resources, S.M. and R.C.; Data Curation, S.M., E.B., D.S. and S.A.; Writing-Original Draft Preparation, S.M., E.B. and R.C.; Writing-Review and Editing, S.M., E.B., M.C., R.C. and D.S.; Supervision, S.M. and R.C.; Project Administration, S.M. and R.C.; and Funding Acquisition, S.M. and R.C.

Funding: This research received funding from: Italian MAECI with "Rita Levi Montalcini Award".

Acknowledgments: We thank P. Di Nardo for giving us the $\mathrm{Lin}^{-} \mathrm{Sca} 1^{+}$human cardiac resident MSCs cell line for collaborative exchanges. ES1408 Cost Action EUALGAE is also acknowledged for networking and knowledge transfer. The authors are grateful to the association of Italian MAECI, MIUR and CRUI foundation for the Rita Levi Montalcini Award for the financial support to the Italy-Israel collaboration.

Conflicts of Interest: The authors declare no conflict of interest.

\section{Abbreviations}

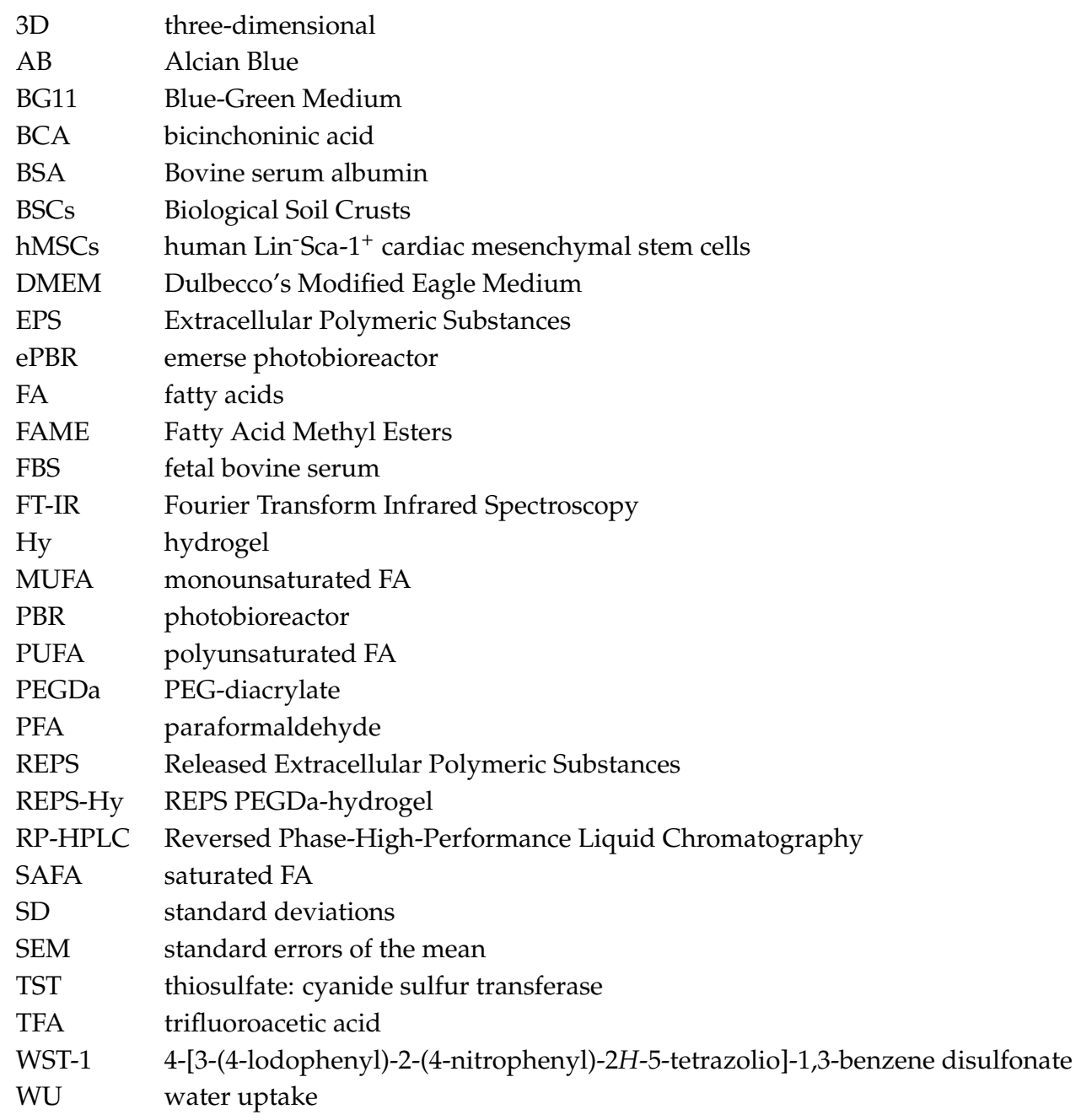

\section{References}

1. Seckbach, J. Algae and Cyanobacteria in Extreme Environments; Springer Science \& Business Media: Berlin, Germany, 2007; ISBN 978-1-4020-6111-0.

2. Grewe, C.B.; Pulz, O. The Biotechnology of Cyanobacteria. In Ecology of Cyanobacteria II; Springer: Dordrecht, The Netherlands, 2012; pp. 707-739. ISBN 978-94-007-3854-6.

3. Brodie, J.; Chan, C.X.; De Clerck, O.; Cock, J.M.; Coelho, S.M.; Gachon, C.; Grossman, A.R.; Mock, T.; Raven, J.A.; Smith, A.G.; et al. The Algal Revolution. Trends Plant Sci. 2017, 22, 726-738. [CrossRef] [PubMed] 
4. Shah, S.A.A.; Akhter, N.; Auckloo, B.N.; Khan, I.; Lu, Y.; Wang, K.; Wu, B.; Guo, Y.W. Structural diversity, biological properties and applications of natural products from cyanobacteria. A review. Mar. Drugs 2017, 15, 354. [CrossRef] [PubMed]

5. Bruno, L.; Di Pippo, F.; Antonaroli, S.; Gismondi, A.; Valentini, C.; Albertano, P. Characterization of biofilm-forming cyanobacteria for biomass and lipid production. J. Appl. Microbiol. 2012, 113, 1052-1064. [CrossRef] [PubMed]

6. Yen, H.W.; Hu, I.C.; Chen, C.Y.; Ho, S.H.; Lee, D.J.; Chang, J.S. Microalgae-based biorefinery-From biofuels to natural products. Bioresour. Technol. 2013, 135, 166-174. [CrossRef] [PubMed]

7. Bharathiraja, B.; Chakravarthy, M.; Ranjith Kumar, R.; Yogendran, D.; Yuvaraj, D.; Jayamuthunagai, J.; Praveen Kumar, R.; Palani, S. Aquatic biomass (algae) as a future feed stock for bio-refineries: A review on cultivation, processing and products. Renew. Sustain. Energy Rev. 2015, 47, 635-653. [CrossRef]

8. Noreen, A.; Zia, K.M.; Zuber, M.; Ali, M.; Mujahid, M. A critical review of algal biomass: A versatile platform of bio-based polyesters from renewable resources. Int. J. Biol. Macromol. 2016, 86, 937-949. [CrossRef] [PubMed]

9. Wijffels, R.H.; Kruse, O.; Hellingwerf, K.J. Potential of industrial biotechnology with cyanobacteria and eukaryotic microalgae. Curr. Opin. Biotechnol. 2013, 24, 405-413. [CrossRef] [PubMed]

10. Velu, C.; Cirés, S.; Alvarez-Roa, C.; Heimann, K. First outdoor cultivation of the N2-fixing cyanobacterium Tolypothrix sp. in low-cost suspension and biofilm systems in tropical Australia. J. Appl. Phycol. 2015, 27, 1743-1753. [CrossRef]

11. Di Pippo, F.; Di Gregorio, L.; Congestri, R.; Tandoi, V.; Rossetti, S. Biofilm growth and control in cooling water industrial systems. FEMS Microbiol. Ecol. 2018, 94, fiy044. [CrossRef] [PubMed]

12. Di Pippo, F.; Ellwood, N.T.W.; Gismondi, A.; Bruno, L.; Rossi, F.; Magni, P.; de Philippis, R. Characterization of exopolysaccharides produced by seven biofilm-forming cyanobacterial strains for biotechnological applications. J. Appl. Phycol. 2013, 25, 1697-1708. [CrossRef]

13. Gismondi, A.; Di Pippo, F.; Bruno, L.; Antonaroli, S.; Congestri, R. Phosphorus removal coupled to bioenergy production by three cyanobacterial isolates in a biofilm dynamic growth system. Int. J. Phytoremediation 2016, 18, 869-876. [CrossRef] [PubMed]

14. Strieth, D.; Schwing, J.; Kuhne, S.; Lakatos, M.; Muffler, K.; Ulber, R. A semi-continuous process based on an ePBR for the production of EPS using Trichocoleus sociatus. J. Biotechnol. 2017, 256, 6-12. [CrossRef] [PubMed]

15. Hill, D.R.; Keenan, T.W.; Helm, R.F.; Potts, M.; Crowe, L.M.; Crowe, J.H. Extracellular polysaccharide of Nostoc commune (Cyanobacteria) inhibits fusion of membrane vesicles during desiccation. J. Appl. Phycol. 1997, 9, 237-248. [CrossRef]

16. Delattre, C.; Pierre, G.; Laroche, C.; Michaud, P. Production, extraction and characterization of microalgal and cyanobacterial exopolysaccharides. Biotechnol. Adv. 2016, 34, 1159-1179. [CrossRef] [PubMed]

17. Ekelhof, A.; Melkonian, M. Microalgal cultivation in porous substrate bioreactor for extracellular polysaccharide production. J. Appl. Phycol. 2017, 29, 1115-1122. [CrossRef]

18. Pereira, S.; Zille, A.; Micheletti, E.; Moradas-Ferreira, P.; De Philippis, R.; Tamagnini, P. Complexity of cyanobacterial exopolysaccharides: Composition, structures, inducing factors and putative genes involved in their biosynthesis and assembly. FEMS Microbiol. Rev. 2009, 33, 917-941. [CrossRef] [PubMed]

19. Rossi, F.; De Philippis, R. Exocellular Polysaccharides in Microalgae and Cyanobacteria: Chemical Features, Role and Enzymes and Genes Involved in Their Biosynthesis. In The Physiology of Microalgae; Developments in Applied Phycology; Springer Nature: New York, NY, USA, 2016; pp. 565-590. ISBN 978-3-319-24943-8.

20. Arias, S.; del Moral, A.; Ferrer, M.R.; Tallon, R.; Quesada, E.; Béjar, V. Mauran, an exopolysaccharide produced by the halophilic bacterium Halomonas maura, with a novel composition and interesting properties for biotechnology. Extremophiles 2003, 7, 319-326. [CrossRef] [PubMed]

21. De Philippis, R.; Vincenzini, M. Outermost polysaccharidic investments of cyanobacteria: Nature, significance and possible applications. Recent Res. Dev. Microbiol. 2003, 7, 13-22.

22. Nichols, C.A.M.; Guezennec, J.; Bowman, J.P. Bacterial Exopolysaccharides from Extreme Marine Environments with Special Consideration of the Southern Ocean, Sea Ice, and Deep-Sea Hydrothermal Vents: A Review. Mar. Biotechnol. 2005, 7, 253-271. [CrossRef] [PubMed]

23. Neu, T.R.; Dengler, T.; Jann, B.; Poralla, K. Structural studies of an emulsion-stabilizing exopolysaccharide produced by an adhesive, hydrophobic Rhodococcus strain. Microbiology 1992, 138, 2531-2537. [CrossRef] [PubMed] 
24. Shepherd, R.; Rockey, J.; Sutherland, I.W.; Roller, S. Novel bioemulsifiers from microorganisms for use in foods. J. Biotechnol. 1995, 40, 207-217. [CrossRef]

25. Di Pippo, F.; Bohn, A.; Congestri, R.; De Philippis, R.; Albertano, P. Capsular polysaccharides of cultured phototrophic biofilms. Biofouling 2009, 25, 495-504. [CrossRef] [PubMed]

26. Flemming, H.C.; Wingender, J. The biofilm matrix. Nat. Rev. Microbiol. 2010, 8, 623-633. [CrossRef] [PubMed]

27. Adessi, A.; Cruz de Carvalho, R.; De Philippis, R.; Branquinho, C.; Marques da Silva, J. Microbial extracellular polymeric substances improve water retention in dryland biological soil crusts. Soil Biol. Biochem. 2018, 116, 67-69. [CrossRef]

28. Gupta, V.; Ratha, S.K.; Sood, A.; Chaudhary, V.; Prasanna, R. New insights into the biodiversity and applications of cyanobacteria (blue-green algae)—Prospects and challenges. Algal Res. 2013, 2, 79-97. [CrossRef]

29. Rossi, F.; Mugnai, G.; De Philippis, R. Complex role of the polymeric matrix in biological soil crusts. Plant Soil 2018, 429, 19-34. [CrossRef]

30. Di Pippo, F.; Bohn, A.; Cavalieri, F.; Albertano, P. ${ }^{1} \mathrm{H}-\mathrm{NMR}$ analysis of water mobility in cultured phototrophic biofilms. Biofouling 2011, 27, 327-336. [CrossRef] [PubMed]

31. Wingender, J.; Neu, T.R.; Flemming, H.C. What are Bacterial Extracellular Polymeric Substances? In Microbial Extracellular Polymeric Substances; Springer: Berlin, Germany, 1999; pp. 1-19. ISBN 978-3-642-64277-7.

32. Sutherland, I.W. Biofilm exopolysaccharides: A strong and sticky framework. Microbiology 2001, 147, 3-9. [CrossRef] [PubMed]

33. Caldorera-Moore, M.; Peppas, N.A. Micro- and Nanotechnologies for Intelligent and Responsive Biomaterial-Based Medical Systems. Adv. Drug Deliv. Rev. 2009, 61, 1391-1401. [CrossRef] [PubMed]

34. Patel, D.M.; Patel, D.K.; Patel, B.K.; Patel, C.N. An overview on intelligent drug delivery systems. Int. J. Adv. Pharm. Rev. 2011, 2, 57-63.

35. Liu, Z.; Jiao, Y.; Wang, Y.; Zhou, C.; Zhang, Z. Polysaccharides-based nanoparticles as drug delivery system. Adv. Drug Deliv. Rev. 2008, 60, 1650-1662. [CrossRef] [PubMed]

36. Seliktar, D. Designing cell-compatible hydrogels for biomedical applications. Science 2012, 336, 1124-1128. [CrossRef] [PubMed]

37. Ciocci, M.; Mochi, F.; Carotenuto, F.; Di Giovanni, E.; Prosposito, P.; Francini, R.; De Matteis, F.; Reshetov, I.; Casalboni, M.; Melino, S.; et al. Scaffold-in-Scaffold Potential to Induce Growth and Differentiation of Cardiac Progenitor Cells. Stem Cells Dev. 2017, 26, 1438-1447. [CrossRef] [PubMed]

38. Rokstad, A.M.A.; Lacík, I.; de Vos, P.; Strand, B.L. Advances in biocompatibility and physico-chemical characterization of microspheres for cell encapsulation. Adv. Drug Deliv. Rev. 2014, 67, 111-130. [CrossRef] [PubMed]

39. Podola, B.; Li, T.; Melkonian, M. Porous Substrate Bioreactors: A Paradigm Shift in Microalgal Biotechnology? Trends Biotechnol. 2017, 35, 121-132. [CrossRef] [PubMed]

40. Chentir, I.; Hamdi, M.; Doumandji, A.; HadjSadok, A.; Ouada, H.B.; Nasri, M.; Jridi, M. Enhancement of extracellular polymeric substances (EPS) production in Spirulina (Arthrospira sp.) by two-step cultivation process and partial characterization of their polysaccharidic moiety. Int. J. Biol. Macromol. 2017, 105, 1412-1420. [CrossRef] [PubMed]

41. Economou, C.N.; Marinakis, N.; Moustaka-Gouni, M.; Kehayias, G.; Aggelis, G.; Vayenas, D.V. Lipid production by the filamentous cyanobacterium Limnothrix sp. growing in synthetic wastewater in suspendedand attached-growth photobioreactor systems. Ann. Microbiol. 2015, 65, 1941-1948. [CrossRef]

42. Rodjaroen, S.; Juntawong, N.; Mahakhant, A.; Miyamoto, K. High biomass production and starch accumulation in native green algal strains and cyanobacterial strains of Thailand. Kasetsart J. Nat. Sci. 2007, 41, 570-575.

43. De Morais, M.G.; Vaz, B.D.S.; De Morais, E.G.; Costa, J.A.V. Biologically Active Metabolites Synthesized by Microalgae. BioMed Res. Int. 2015, 2015. [CrossRef] [PubMed]

44. Das, U.N. Arachidonic acid and other unsaturated fatty acids and some of their metabolites function as endogenous antimicrobial molecules: A review. J. Adv. Res. 2018, 11, 57-66. [CrossRef] [PubMed]

45. Stengel, D.B.; Connan, S.; Popper, Z.A. Algal chemodiversity and bioactivity: Sources of natural variability and implications for commercial application. Biotechnol. Adv. 2011, 29, 483-501. [CrossRef] [PubMed]

46. Bellou, S.; Baeshen, M.N.; Elazzazy, A.M.; Aggeli, D.; Sayegh, F.; Aggelis, G. Microalgal lipids biochemistry and biotechnological perspectives. Biotechnol. Adv. 2014, 32, 1476-1493. [CrossRef] [PubMed] 
47. Gayathri, M.; Shunmugam, S.; Mugasundari, A.V.; Rahman, P.K.S.M.; Muralitharan, G. Growth kinetic and fuel quality parameters as selective criterion for screening biodiesel producing cyanobacterial strains. Bioresour. Technol. 2018, 247, 453-462. [CrossRef] [PubMed]

48. Plaza, M.; Herrero, M.; Cifuentes, A.; Ibáñez, E. Innovative Natural Functional Ingredients from Microalgae. J. Agric. Food Chem. 2009, 57, 7159-7170. [CrossRef] [PubMed]

49. Steinhoff, F.S.; Karlberg, M.; Graeve, M.; Wulff, A. Cyanobacteria in Scandinavian coastal waters-A potential source for biofuels and fatty acids? Algal Res. 2014, 5, 42-51. [CrossRef]

50. Galhano, V.; de Figueiredo, D.R.; Alves, A.; Correia, A.; Pereira, M.J.; Gomes-Laranjo, J.; Peixoto, F. Morphological, biochemical and molecular characterization of Anabaena, Aphanizomenon and Nostoc strains (Cyanobacteria, Nostocales) isolated from Portuguese freshwater habitats. Hydrobiologia 2011, 663, 187-203. [CrossRef]

51. Koller, M.; Muhr, A.; Braunegg, G. Microalgae as versatile cellular factories for valued products. Algal Res. 2014, 6, 52-63. [CrossRef]

52. Funk, C.D. Prostaglandins and Leukotrienes: Advances in Eicosanoid Biology. Science 2001, 294, 1871-1875. [CrossRef] [PubMed]

53. Cardozo, K.H.M.; Guaratini, T.; Barros, M.P.; Falcão, V.R.; Tonon, A.P.; Lopes, N.P.; Campos, S.; Torres, M.A.; Souza, A.O.; Colepicolo, P.; et al. Metabolites from algae with economical impact. Comp. Biochem. Physiol. Part C Toxicol. Pharmacol. 2007, 146, 60-78. [CrossRef] [PubMed]

54. Judé, S.; Roger, S.; Martel, E.; Besson, P.; Richard, S.; Bougnoux, P.; Champeroux, P.; Le Guennec, J.Y. Dietary long-chain omega-3 fatty acids of marine origin: A comparison of their protective effects on coronary heart disease and breast cancers. Prog. Biophys. Mol. Biol. 2006, 90, 299-325. [CrossRef] [PubMed]

55. Maehre, H.K.; Jensen, I.J.; Elvevoll, E.O.; Eilertsen, K.E. w-3 Fatty Acids and Cardiovascular Diseases: Effects, Mechanisms and Dietary Relevance. Int. J. Mol. Sci. 2015, 16, 22636-22661. [CrossRef] [PubMed]

56. Rose, D.P.; Connolly, J.M. Omega-3 fatty acids as cancer chemopreventive agents. Pharmacol. Ther. 1999, 83, 217-244. [CrossRef]

57. Xu, Y.; Qian, S.Y. Anti-cancer Activities of w-6 Polyunsaturated Fatty Acids. Biomed. J. 2014, 37, 112-119. [CrossRef] [PubMed]

58. Molfino, A.; Amabile, M.I.; Mazzucco, S.; Biolo, G.; Farcomeni, A.; Ramaccini, C.; Antonaroli, S.; Monti, M.; Muscaritoli, M. Effect of Oral Docosahexaenoic Acid (DHA) Supplementation on DHA Levels and Omega-3 Index in Red Blood Cell Membranes of Breast Cancer Patients. Front. Physiol. 2017, 8, 549. [CrossRef] [PubMed]

59. Ciocci, M.; Iorio, E.; Carotenuto, F.; Khashoggi, H.A.; Nanni, F.; Melino, S. $\mathrm{H}_{2}$ S-releasing nanoemulsions: A new formulation to inhibit tumor cells proliferation and improve tissue repair. Oncotarget 2016, 7, 84338-84358. [CrossRef] [PubMed]

60. García, J.L.; de Vicente, M.; Galán, B. Microalgae, old sustainable food and fashion nutraceuticals. Microb. Biotechnol. 2017, 10, 1017-1024. [CrossRef] [PubMed]

61. Lee, J.M.; Lee, H.; Kang, S.; Park, W.J. Fatty Acid Desaturases, Polyunsaturated Fatty Acid Regulation, and Biotechnological Advances. Nutrients 2016, 8, 23. [CrossRef] [PubMed]

62. Potts, M. Desiccation tolerance of prokaryotes. Microbiol. Rev. 1994, 58, 755-805. [PubMed]

63. Kuhne, S.; Strieth, D.; Lakatos, M.; Muffler, K.; Ulber, R. A new photobioreactor concept enabling the production of desiccation induced biotechnological products using terrestrial cyanobacteria. J. Biotechnol. 2014, 192, 28-33. [CrossRef] [PubMed]

64. Comte, S.; Guibaud, G.; Baudu, M. Relations between extraction protocols for activated sludge extracellular polymeric substances (EPS) and complexation properties of $\mathrm{Pb}$ and Cd with EPS. Enzyme Microb. Technol. 2006, 38, 246-252. [CrossRef]

65. Comte, S.; Guibaud, G.; Baudu, M. Biosorption properties of extracellular polymeric substances (EPS) resulting from activated sludge according to their type: Soluble or bound. Process Biochem. 2006, 41, 815-823. [CrossRef]

66. Guibaud, G.; Comte, S.; Bordas, F.; Dupuy, S.; Baudu, M. Comparison of the complexation potential of extracellular polymeric substances (EPS), extracted from activated sludges and produced by pure bacteria strains, for cadmium, lead and nickel. Chemosphere 2005, 59, 629-638. [CrossRef] [PubMed]

67. Mishra, A.; Jha, B. Isolation and characterization of extracellular polymeric substances from micro-algae Dunaliella salina under salt stress. Bioresour. Technol. 2009, 100, 3382-3386. [CrossRef] [PubMed] 
68. Trabelsi, L.; M'sakni, N.H.; Ouada, H.B.; Bacha, H.; Roudesli, S. Partial characterization of extracellular polysaccharides produced by cyanobacterium Arthrospira platensis. Biotechnol. Bioprocess Eng. 2009, 14, $27-31$. [CrossRef]

69. Ophir, T.; Gutnick, D.L. A role for exopolysaccharides in the protection of microorganisms from desiccation. Appl. Environ. Microbiol. 1994, 60, 740-745. [PubMed]

70. Ganguly, K.; Chaturvedi, K.; More, U.A.; Nadagouda, M.N.; Aminabhavi, T.M. Polysaccharide-based micro/nanohydrogels for delivering macromolecular therapeutics. J. Control. Release 2014, 193, 162-173. [CrossRef] [PubMed]

71. Akiyoshi, K.; Kobayashi, S.; Shichibe, S.; Mix, D.; Baudys, M.; Wan Kim, S.; Sunamoto, J. Self-assembled hydrogel nanoparticle of cholesterol-bearing pullulan as a carrier of protein drugs: Complexation and stabilization of insulin. J. Control. Release 1998, 54, 313-320. [CrossRef]

72. Sarmento, B.; Ribeiro, A.; Veiga, F.; Ferreira, D. Development and characterization of new insulin containing polysaccharide nanoparticles. Colloids Surf. B Biointerfaces 2006, 53, 193-202. [CrossRef] [PubMed]

73. Chalasani, K.B.; Russell-Jones, G.J.; Jain, A.K.; Diwan, P.V.; Jain, S.K. Effective oral delivery of insulin in animal models using vitamin B12-coated dextran nanoparticles. J. Control. Release 2007, 122, 141-150. [CrossRef] [PubMed]

74. Yuan, W.; Hu, Z.; Su, J.; Wu, F.; Liu, Z.; Jin, T. Preparation and characterization of recombinant human growth hormone- $\mathrm{Zn}^{2+}$-dextran nanoparticles using aqueous phase-aqueous phase emulsion. Nanomed. Nanotechnol. Biol. Med. 2012, 8, 424-427. [CrossRef] [PubMed]

75. Liu, L.; Pohnert, G.; Wei, D. Extracellular metabolites from industrial microalgae and their biotechnological potential. Mar. Drugs 2016, 14, 191. [CrossRef] [PubMed]

76. Calvert, P. Materials science. Printing cells. Science 2007, 318, 208-209. [CrossRef] [PubMed]

77. Mironov, V.; Boland, T.; Trusk, T.; Forgacs, G.; Markwald, R.R. Organ printing: Computer-aided jet-based 3D tissue engineering. Trends Biotechnol. 2003, 21, 157-161. [CrossRef]

78. Franca, M.B.; Panek, A.D.; Eleutherio, E.C. Oxidative stress and its effects during dehydration. Comp. Biochem. Physiol. A Mol. Integr. Physiol. 2007, 146, 621-631. [CrossRef] [PubMed]

79. Rippka, R.; Deruelles, J.; Waterbury, J.B.; Herdman, M.; Stanier, R.Y. Generic Assignments, Strain Histories and Properties of Pure Cultures of Cyanobacteria. J. Gen. Microbiol. 1979, 111, 1-61. [CrossRef]

80. Mata, T.M.; Martins, A.A.; Caetano, N.S. Microalgae for biodiesel production and other applications: A review. Renew. Sustain. Energy Rev. 2010, 14, 217-232. [CrossRef]

81. Ahmed, M.; Moerdijk-Poortvliet, T.C.W.; Wijnholds, A.; Stal, L.J.; Hasnain, S. Isolation, characterization and localization of extracellular polymeric substances from the cyanobacterium Arthrospira platensis strain MMG-9. Eur. J. Phycol. 2014, 49, 143-150. [CrossRef]

82. Dubois, M.; Gilles, K.A.; Hamilton, J.K.; Rebers, P.A.; Smith, F. Colorimetric Method for Determination of Sugars and Related Substances. Anal. Chem. 1956, 28, 350-356. [CrossRef]

83. Ehimen, E.A.; Sun, Z.F.; Carrington, C.G. Variables affecting the in situ transesterification of microalgae lipids. Fuel 2010, 89, 677-684. [CrossRef]

84. Karadağ, E.; Üzüm, Ö.B.; Saraydin, D. Water uptake in chemically crosslinked poly(acrylamide-co-crotonic acid) hydrogels. Mater. Des. 2005, 26, 265-270. [CrossRef]

85. Ciocci, M.; Cacciotti, I.; Seliktar, D.; Melino, S. Injectable silk fibroin hydrogels functionalized with microspheres as adult stem cells-carrier systems. Int. J. Biol. Macromol. 2018, 108, 960-971. [CrossRef] [PubMed]

86. Colnaghi, R.; Pagani, S.; Kennedy, C.; Drummond, M. Cloning, sequence analysis and overexpression of the rhodanese gene of Azotobacter vinelandii. Eur. J. Biochem. 1996, 236, 240-248. [CrossRef] [PubMed]

87. Sabelli, R.; Iorio, E.; Martino, A.D.; Podo, F.; Ricci, A.; Viticchiè, G.; Rotilio, G.; Paci, M.; Melino, S. Rhodanese-thioredoxin system and allyl sulfur compounds. FEBS J. 2008, 275, 3884-3899. [CrossRef] [PubMed]

88. Sörbo, B.H. Rhodanese. Acta Chem. Scand. 1973, 7, 1129-1133. [CrossRef]

89. Forte, G.; Pietronave, S.; Nardone, G.; Zamperone, A.; Magnani, E.; Pagliari, S.; Pagliari, F.; Giacinti, C.; Nicoletti, C.; Musaró, A.; et al. Human Cardiac Progenitor Cell Grafts as Unrestricted Source of Supernumerary Cardiac Cells in Healthy Murine Hearts. Stem Cells 2011, 29, 2051-2061. [CrossRef] [PubMed]

90. Koyanagi, M.; Kawakabe, S.; Arimura, Y. A comparative study of colorimetric cell proliferation assays in immune cells. Cytotechnology 2016, 68, 1489-1498. [CrossRef] [PubMed] 
91. Morishita, M.; Lowman, A.M.; Takayama, K.; Nagai, T.; Peppas, N.A. Elucidation of the mechanism of incorporation of insulin in controlled release systems based on complexation polymers. J. Control. Release. 2002, 81, 25-32. [CrossRef]

92. Lowman, A.M.; Morishita, M.; Nagai, T.; Peppas, N.A. Method for Oral Delivery of ProteinsA Hydrogel Matrix. U.S. Patent Application WO1998043615 A1, 1998. 